\title{
T 500
}

.C1 W14 

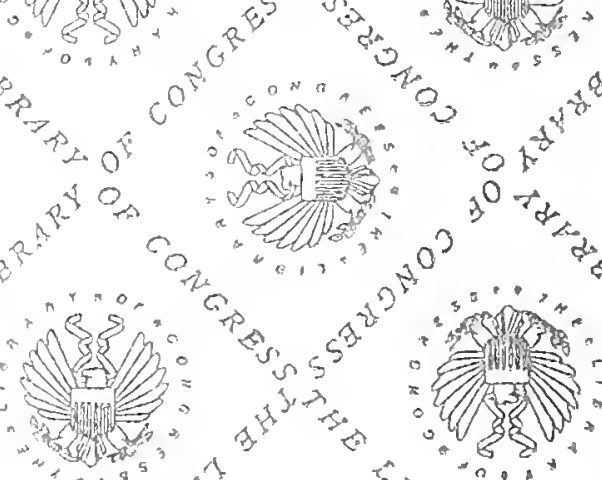





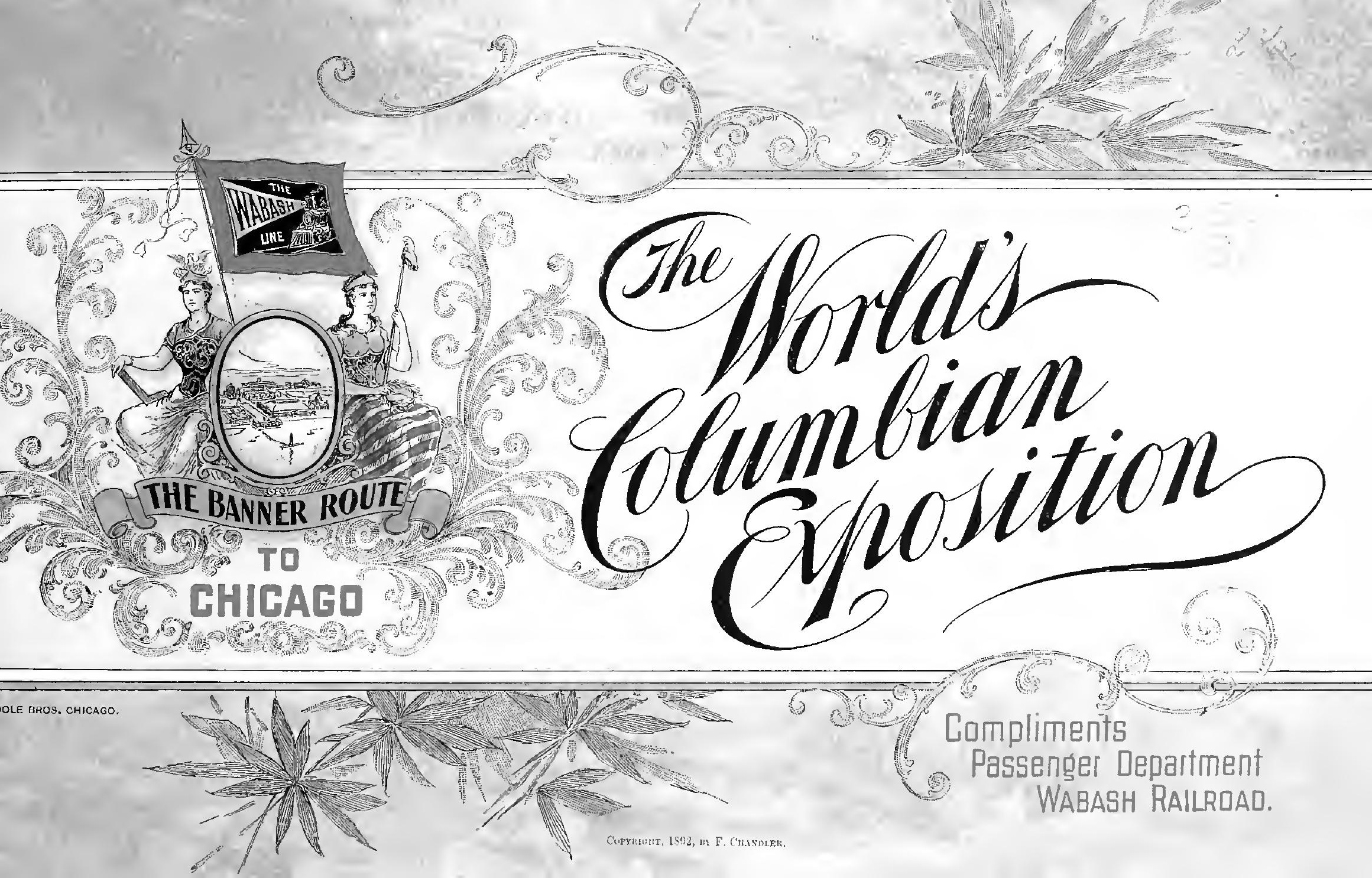




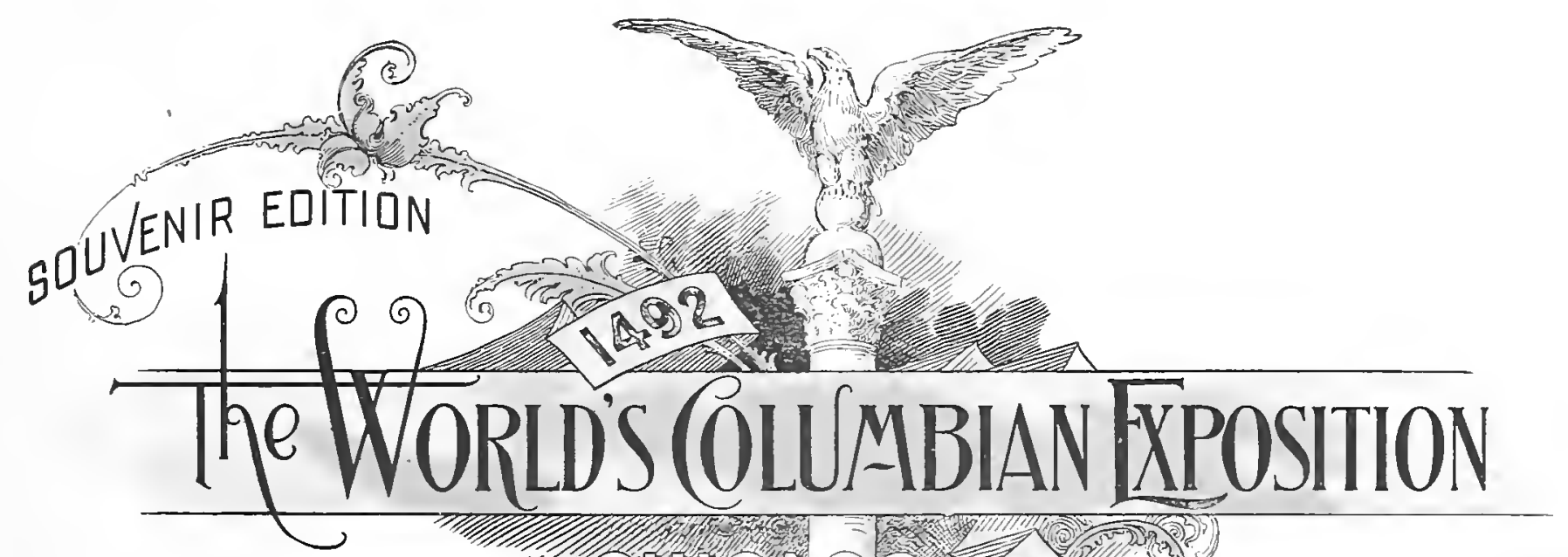

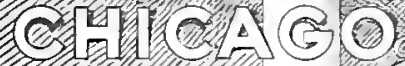

CHAS. M. HAYS, General Manager,

F. CHANDLER, Gen'I Passenger and Ticket Agent,

C. S. CRANE, Ass't Gen'l Pass'r and Ticket Agent, ST. LOUIS, MO.

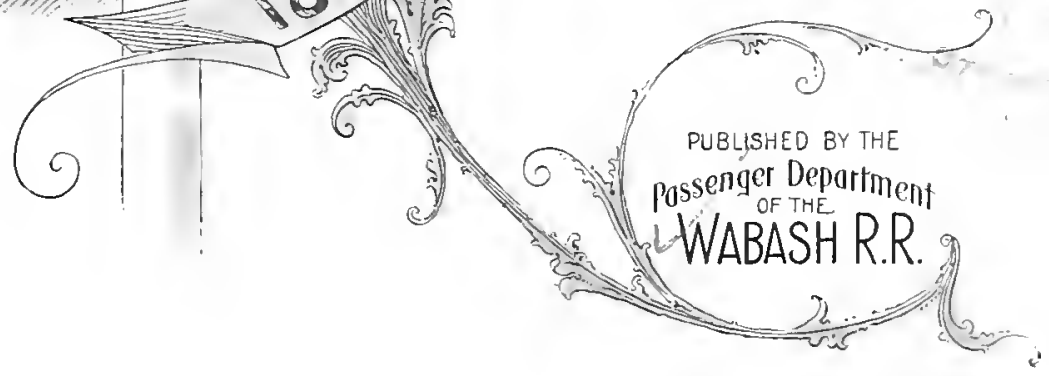




\section{BIRD'S-EYE VIEW OF THE WORLD'S FAIR.}

THE magnificent City of White, reared as if by magic within two years, at Jackson Park, when viewed in connection with the broad stretch of Lake Michigan and the placid surface of sparkling lagoons, takes on a truly Venetian aspect. The brightest ideas of the foremost architectural talent of America take form in the imposing edifices which lend additional charm to the attractive landscape. Standing on an elevation such as the one afforded by the dome of the Administration building, the visitor sweeps with his gaze 600 broad acres of improved land. Shrubbery, flowers and spacious lawns surround each structure, and, in contrast with the whiteness of the buildings, heighter most delightfully the effect on the observer's vision. Picturesquely grouped in the northern portion of the vast area of green are the State buildings and the pleasant headquarters of the foreign nations. Conspicuous among the State club. houses is the building erected by the State of Illinois, costing upwards of $\$ 250,000$ out of a total appropriation of $\$ 800,000$ by the State Legislature. In this locality, and in the old improved part of Jackson Park, is the Palace of Fine Arts, the only building on the grounds which is made of brick. Absolutely fireproof, it is designed to house the art treasures of the world.
Across the lagoon from the Palace of Fine Arts is the United States Government building, which is separated from the Fish and Fisheries structure by a broad channel. The most prominent building in the collection of massive structures is the Manufactures, or Main building, a giant among giants. The pier, extending into the lake, is 1,000 feet long, and affords a landing place for excursion steamers. The grand avenue extends westward through the park from the pier and is several hundred feet wide. A mile distant down this boulevard is the central building of the entire group, the Administration. Close at hand is the one dense spot in the park where primitive nature is preserved. This is the Wooded Island, which is to afford an attractive site for the unique exhibit from Japan. The southwestern section of the park affords location for the numerous railroad tracks bunched in the terminal station. The Horticultural and Transportation buildings are to the northward and enter the visitor's vision soon after he lands within the grounds. Still north of them, and adjoining the part reserved for State buildings, is the IVoman's edifice, which, with its tenants, will lend lustre to what was, not long since, a desolate waste. 
$\mathrm{M}$

ORE than four hundred years ago it was, or to be exact, on the third day of August, I 492, that the great discoverer set sail from Palos pier, on the voyage that was to change the course of history, and give a new world to civilization. Thus farreaching were the results of his daring enterprise. But no one then, not even the explorer hinself, could anticipate such wonderful effects. Three little vessels formed the fleet, and they were manned by but 120 sailors. The largest ship, the Santa Maria, on which flew the admiral's pennant, was of about Ioo tons burden, while the other two, the Pinta and the Nina, were still smaller vessels, called caravels, with no decks amidships, but built high out of the water at stem and stern. The boats were unseaworthy as well as small, and the Pinta unshipped her rudder before they reached the Canary Islands.

This departure of Columbus for his voyage over the "unknown sea" was the culmination of years of effort and his final success came only when he was almost at the extremity of discouragement. His labors to secure recognition for his advanced theories began in early manhood. In Lisbon the Genoese was living before he was thirty years of age, having abandoned his roving life and setiled down to making a living by drawing maps and sea-charts. He married the daughter of a renowned navigator, and inheriting his charts, became by their study more and more convinced of the truth of his theories as to the rotundity of the world and the possibility of reaching India by sailing westward. Then began his wanderings from court to court-Genoa, Portugal and Spain receiving him but coldly, as one who in our day would be called a "crank." It was at the end of his efforts before the monarchs, Ferdinand and Isabella, when he had actually turned his back upon Spain to go to England with the offer of his plans, that a messenger from the queen called him back to her. Her promise to pledge her private jewels if necessary for the expenses of fitting up the ships, was the means of procuring ships and men, and so the great discovery was saved for Spain. Two of the little ships were commanded by the brothers Pinzon, who had been friends to Columbus during his later years of effort. Their fame has come to this day because of the help they gave to Columbus, and the confidence in him that they displayed. And so as we see the sailors rowing "the admiral of the ocean seas" off to his ship, there on the pier of Palos is the good Prior extending his hands in blessing of commander and fleet and undertaking. 


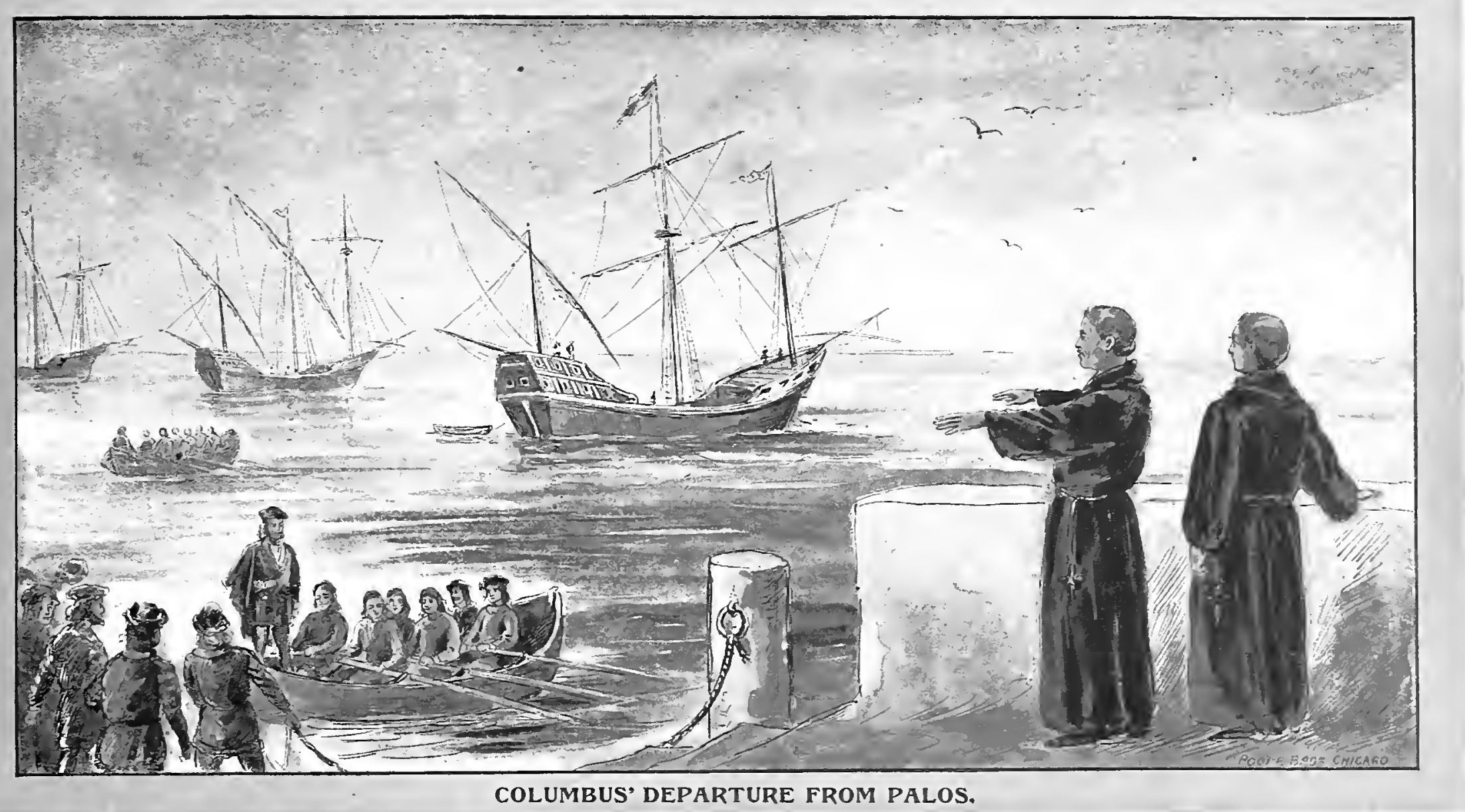


THE crowning glory of all the great structures of the World's Columbian Exposition is the Administration building, which is pictured on the opposite page. It is the most ornate of the main buildings and has been pronounced by every one the gem of all the jewels of the fair. With its great golden dome thrust far on high it dominates as well as illuminates the court at the head of which it stands. It has the most commanding position of ail on the grounds. The architect of the structure is that masterly artist, Richard M. Hunt, of New lork. The building is in the form of four pavilions, one at each of the four angles of the square of the plain and connected by a great central dome, 125 feet in diameter and 250 feet high. In the center of each façade $i s$ a recess 32 feet wide. within which is a grand arched entrance to the building. The greneral design is in the style of the French renaissance, carried out in the academic manner of the Ecole des Beaux Arts. The first great story is on the Doric order and of heroic proportions sumounted by a lofty balustrade. Externally the design may be divided, in its height, with three principal stages. The first stanc corresfonds in height with the buldings grouped around it, which are about sixty-five feet high. The second stage of the same height is a continuation of the central rotunda, I75 feet square, surrounded on all sides by an open colonnade 20 feet wide and to feet high, with columns four feet in diameter. The third stage consists of the base of the great dome, and the dome itself, rising in graceful lines richly ornamented with moulded ribs and sculptured panels. This dome is coated with aluninum bronze, the cost of which was $\$ 54,000$. On each side of the great entrance are groups of sculpture. The interior features rival in beauty the exterior. Just within each grand entrance is a hall provided with broad stairways and swift elevators. The interior of the dome rises 200 feet from the floor, and an opening, 50 feet square, admits a flood of light. It is enriched with panels filled with sculptures and immense paintings, representing the arts and sciences. The corner pavilions appear small in the picture, but they are really four-story office buildings and they contain the offices of administration, the fire and police departments, board and committee rooms, postoffice, bank and restaurant, and rooms for public comfort. Noble interior and exterior galleries at great height make delightful stations for a bird's-eye view of all that is within range of vision. 
A DNINISTRATION.

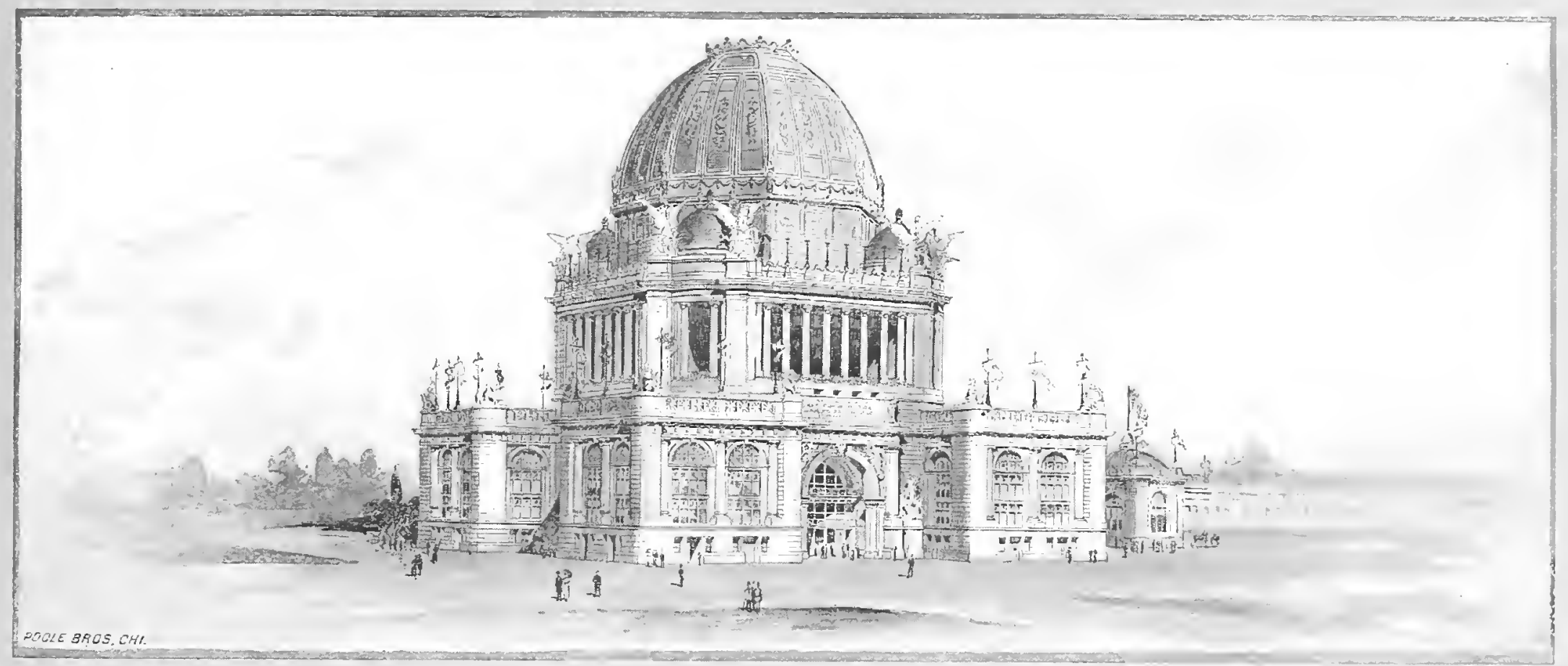

Area, One and Six.Tenths Acres. Cost, $\$+50,000$.

Dimensions, $260 \times 260$ Feet. 
THE LANDING OF COLUMBUS.

A CROSS a waste of waters the Pinta, the Nina and the Santa Maria sailed for more than two months before the result for which their commander was striving was attained. At the end of the first month of the voyage they reached the Canary Islands. After that they passed many desolate day's on the sea, with the sailors discontented by day and weeping by night. It took all of the tact that Columbus had at his command to quiet them. Once the sailors plotted to throw him overboard, but he was keen and watchful, and his dignity held them in check. At length, however, he was obliged to tell them that if they saw no land for three days he would comsent to turn back. l magine the anxiety that he felt after giving that promise. Was it possible that he would be forced to give up all his long-nursed hopes and forego the glory of discovery, and all because of a handful of fearful and ignorant sailors? But the outcome was as strange as a miracle. In the morning of the third day a sailor standing aloft with his seaman's glass espied land. The joy guns were fired to let the men upon the other vessels know of this wondrous fact. They sailed all day toward land. Anchor was cast over night, and the following morning Columbus was rowed to the shore. Nusic and waring hanners accompanied the cortege. High above all flonted the great, golden standard of Ferdinand and Isabella. What blame can there be if at such a time there came to Columbus a thought of triumph, that he had proven himself right in his theories, that he had won eternal fame for himself, and that those nations which had rejected his services, and those men who had sneered at him, would now be cast down at the thought of their loss? Is there any man so great that he would not in such a circumstance feel the same thrill of pride? And so the commander and his seamen landed upon the island of the south, which they named San Salvador, on the morning of October 12,1492 . With sword and cross they took possession of it for civilization and christianity. We do not know at this day whether the land that he first reached was that which we call San Salvador or not. The natives called it Guanahani. It was a flat island with a shallow lake in the center and not especially inviting, so the men sailed on and visited Cuba, Hayti and others of the West Indies. Columbus did not doubt that he had found Cathay. But though this was a mistake, and though other voyagers, the Norsemen, had reached the continent hundreds of years before, yet the credit of discovery is due to Columbus, for he led the way for modern navigators, and so opened the Western Hemisphere to occupation and civilization. 


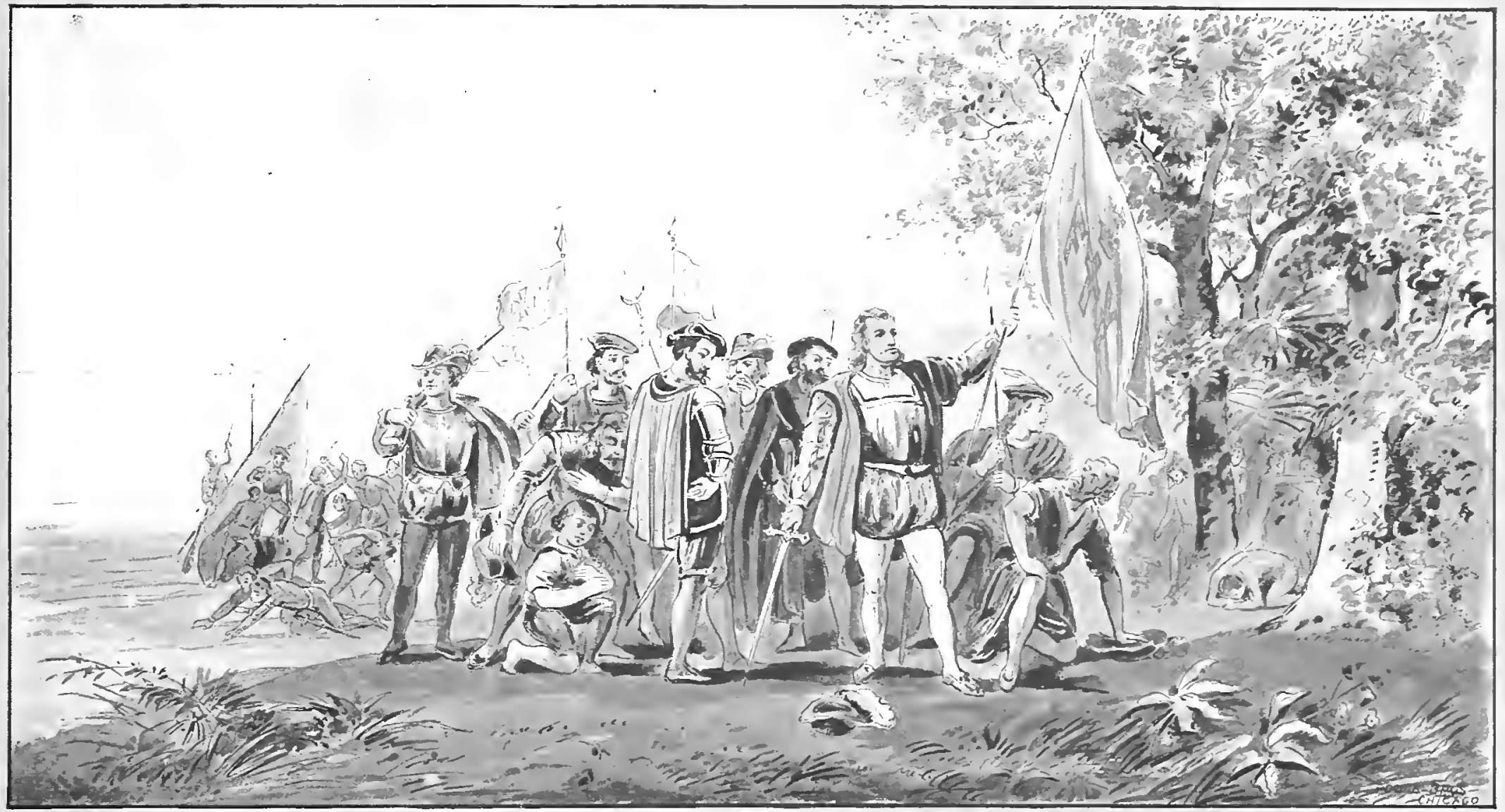

LANDING OF COLUMBUS. 
THE U. S. GOVERNMENT BUILDING.

TATIONAL legislation and national investment have been liberal to the World's Fair, and thus has been guaranteed the promise that the enterprise would be national in character, rather than local. It was the invitation sent to all nations by the Presiclent of the United States to participate in the Exposition that gave the immense impetus to the foreign exhibitors who are now represented so magnificently in the great buildings; and the structure which has been erected by the Government for the display of its own exhibits is one of the grandest uf all the host. lts location is a delightful one, as it stands near the lake and facing the beautiful open lawn which is called the Government Plaza. It is on this lawn that all military clrills and other reviews will be given. The buildings of England. Germany and Mexico are near by, to the northward.

The most prominent architectural feature of this edifice is an imposing central dome, I 20 feet in diameter and 150 feet livgh, the floor of which has been kept free from exhibits and is used for a popular promenade. The building fronts to the west and connects on the north, by a bridge over the lagoon, with the building of the Fisheries exhibit, which by its very nature is largely governmental in character. The south half of the Government building is devoted to the exhibits of the Postoffice Department, Treasury Departmer:c, War Department and the Department of Agriculture. The north half is devoted to the interests of the Fisheries Commission, Smithsonian Institution and Interior Department. The State Department exhibit extends from the rotuncla to the east end, and the exhibit of the Department of Justice from the rotunda to the west end of the building. Adjoining the building are four other governmental exhibits, which are at the same time for practical use on the grounds. One is the Amy Hospital, another is the Weather Bureau building, another is the Light House, and the fourth is the Life-Saving Station. These are not, by any means, the least interesting portion of the entire exhibit. To most of us, who have not been office-holders and do not want to be, the Government at Washington is something very far away and very unfamiliar. The kind of familiarity that breeds contempt is not to be desired, but if this exhibit, made by the great departments of our Grovermment, can better acquaint the people with the methods and work which they are doing, as the intention is, it is certainly one of the best features of the whole Exposition. 


\section{U. S. GOVERNMENT.}

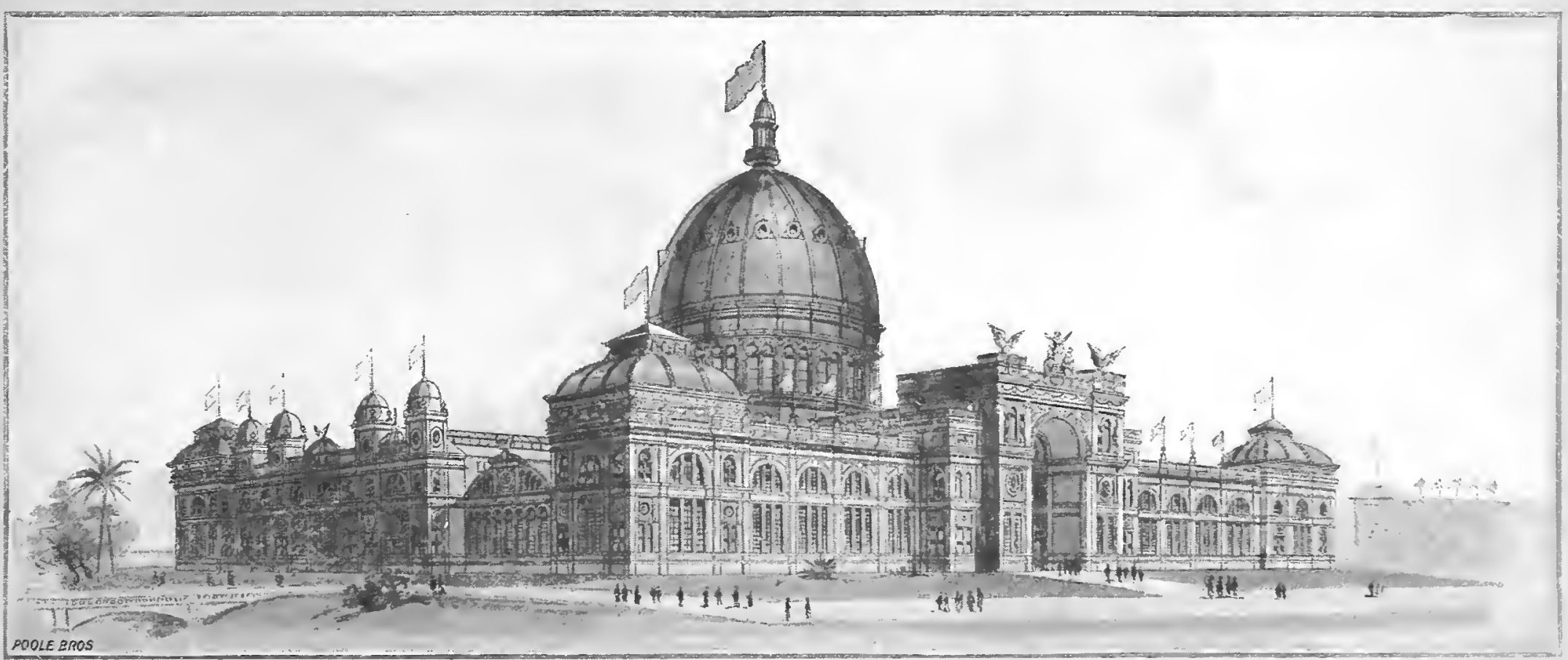

Area, Three and Four-Tenths Acres. Cost, $\$ 400,000$. 


\section{BALBOA DISCOVERING THE PACIFIC.}

CHE earlier navigators who set sail from Europe to explore the unknown lands across the deep, from the time of Columbus himself, expected and desired only to find the rich regions of the Orient and the countries bordering upon the "South Sea." Columbus thought that he had reached the goal of his ambition, and until his death believed that he had discovered the coasts of the Indies. To him, those seas that he sailed were the waters that washed the shores of Cipango and Cathay. But it was reserved for another voyager, Tasco Nunez de Balboa, to gain the first sight granted to European of the eastern confines of that great sea whose western waves lave the lands of the Orient.

Balboa was a Spaniard, an exccllent specimen of that class of freebooter-discoverers who overran the southern half of the New World, and of which Pizarro and Cortez, who were fitted for thcir future careers in the same school and region with Balboa, were still more brilliant instances. To escape from his creditors in Hispañola, he concealed himself on board a vessel bound for the Caribbean Sea. By his intrigues and force of character, he had soon deposed the commander of the expedition and raised himself to the supreme rule. From the son of a chief he learned that to the west there was another sea. In
September, 1513, he started from Darien to find it. Hostile tribes of Indians blocked his way at every step, and the party had to literaily hew its way through flesh. At length the invaders reached a high mountain from the top of which, the Indians said, the southern sea was in sight. Balboa ordered his men to halt while he climbed up alone. Far beneath him, on the other side, lay the blue ocean, sparkling and glorious in the sunlight, stretching as far as the eye could reach. 1t was for this that all the great navigators of the world had been searching for nearly twenty years, and Balboa fell to the ground and gave thanks to God. Then in an ecstacy of delight he beckoned his followers to come to him, and pointed out his wonderful discovery. He declared that all the country round about belonged to the $\mathrm{K}$ ing of Spain. Then, after other days of effort, he reached the waters themselves, and marching in up to his thighs, he claimed the ocean and all the lands on its shores for the same ruler. He was appointed by the King to be Adelantado over the sea he had discovered, and continued the explorations of the western coast; but five years later he was beheaded by the Governor of Darien after the mockery of a trial. He fell a victim to jealousy. 


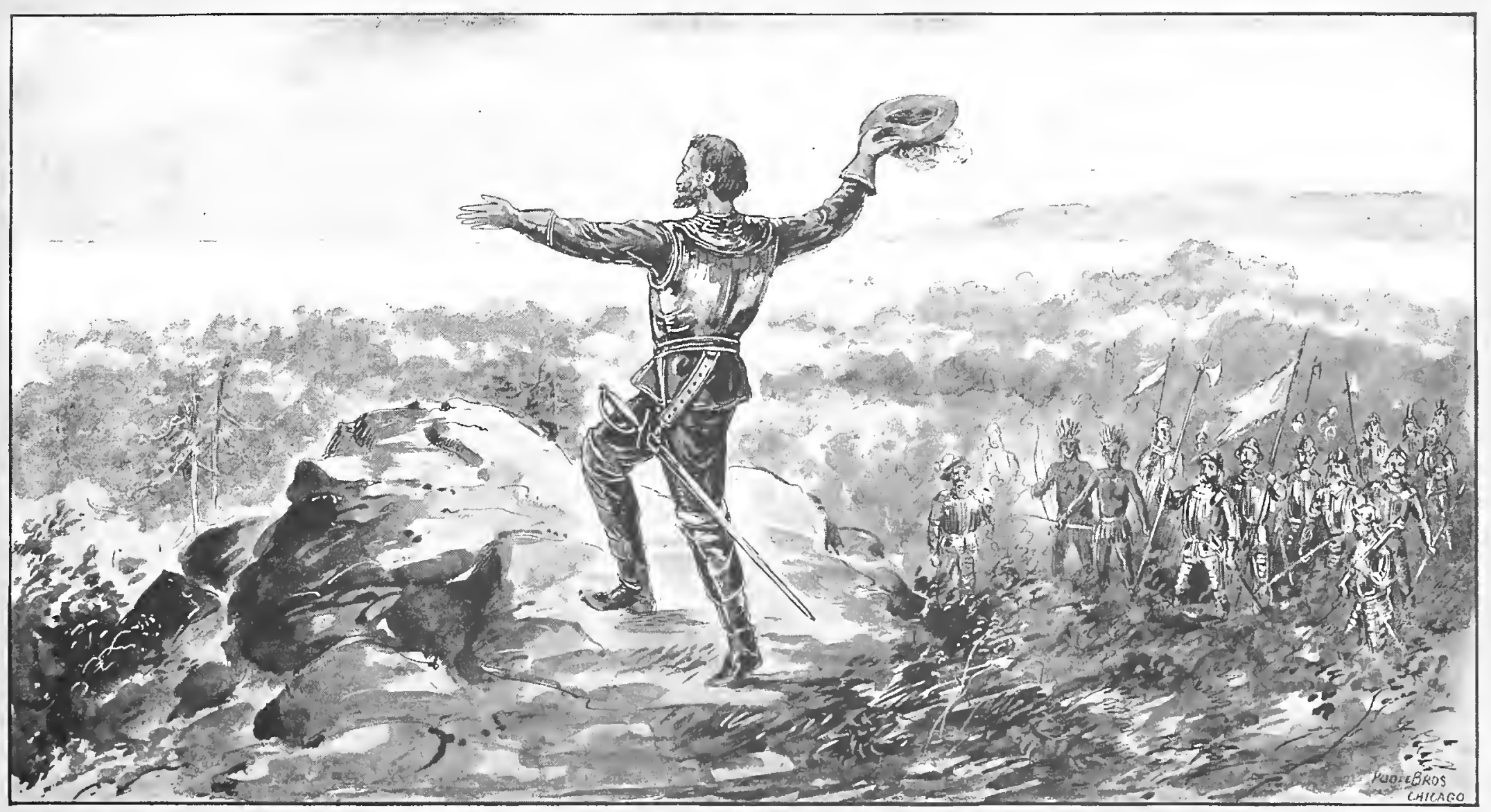

BALboa discovering THE PACIFIC. 
MANUFACTURES AND LIBERAL ARTS.

DEXalmost fails, and one hesitates at the effort, to describe the leviathan of thestructures of the Exposition, the Manufactures and Liberal Arts building. It is not that the building is intricate or complex in its architecture-it is simply its immensity that aprals, and the mass of interesting letails that must be condensed to a minimum. It is the largest house that the world contains. To walls around it is to travel a mile. The great trusses of the roof, the sreatest everbuilt, have a span of 382 feet. The height of them over the center of the floor is 212 feet. It contains $17,000,000$ feet of lumber, 12,000,000 pounds of steel in the trusses over the central hall, and 2,000,000 pounds of iron in the roof of the nave. It will be seen that this is one instance in which statistics are interesting. The architect who designed the building, George B. Post of New Fork, did not at first include the vast roof, now one of the wonders of the worle. lnstead was included a central court with the features of a garden; but when more space was demanded than was included in the outer pavilions which contained the court, the as chitect drew a charcoal line over the plan of the building, marking a curve that bridged the central space. That stroke of the charcoal added $\$ 50,000$ to the cost of the building. It is four times larger than the old Roman Colosseum, which seated 80,000 persons.
It required five carloads of nails to fasten the 215 carloads of flooring to the joints. There are eleven acres of skylinhts and forty carloads of glass in the roof. The long array of columns and arches which its façades present, is relieved from monotony by very elaborate ornamentation. $l_{n}$ this, female figures symbolical of the various arts and sciences, play a conspicuous and attractive part. The four great entrances are designed in the manner of triumphal arches, the central arch of each being forty feet wide and eighty feet high. At each corner are pavilions forming arched entrances, in harmony with the great portals. The building occupies the most conspicuous place in the grounds. It faces the lake with nothing except lawns and promenades between. North of it is the Government building, south the harbor, and west the Electricity building and the lagoon separating it from the great island, which in part is wooded and in part radiant with acres of flowers of varied hue. The exhibits that are displayed within this edifice are so numerous and varied that the visitor may spend weeks in viewing them without exhausting the pleasure. Here nind and muscle are united, and whatever machinery or inventions have accomplished is displayed in its perfection. 
MANUFACTURES AND LIBERAL ARTS.

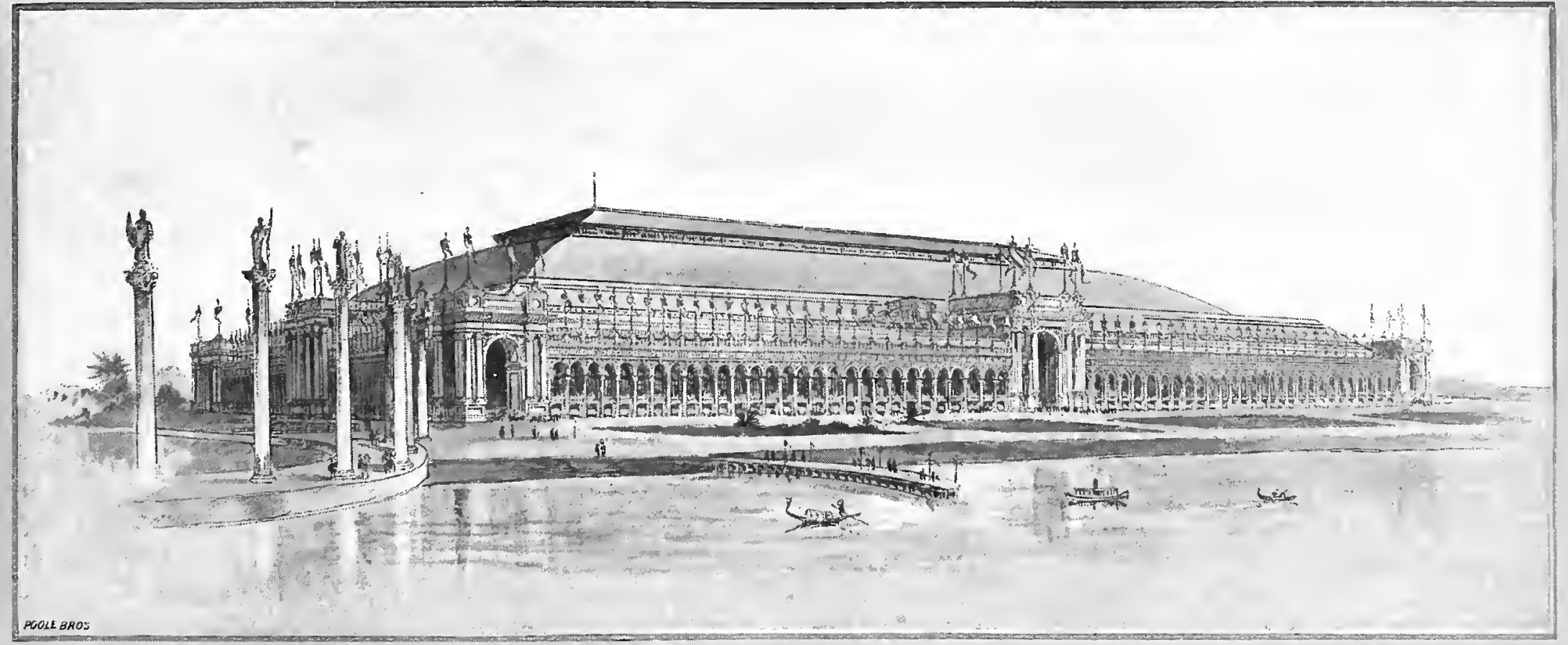

Area, Forty-Four Acres. Cost, $\$ 1,500,000$

Dimensions, $787 \times 1687$ Feet. 


\section{DE SOTO DISCOVERING THE MISSISSIPPI.}

$\mathrm{F}^{\mathrm{F}}$ all the romantic and dramatic episodes in the history of discovery and exploration in America, none surpasses in interest the great expedition of Fernando de Soto, its results and its ending. De Soto was one of the most energetic and venturesome of all the Spanish grandees who sought gold in the new-found lands. He had gone to Peru with Pizarro, and, starting from Spain like many others with nothing but "blade and buckler," had come back with wealth. In spite of the disastrous results of every expedition to Florida, the adventurous Spaniards still believed in the value of the country, and that somewhere in its interior were to be found enormous riches. De Soto appeared at court, and, with a band of followers in gorgeous attire, made lavish display of the wealth he had won in Peru. He was given a commission as Adelantado of Florida, and was permitted to enlist followers for taking possession of the country. Gentlemen of high birth and soldiers of fortune from all over Spain and Portugal flocked to join him, and there seemed to be a real craze for going on this trip. Some went so far as to sell their estates to buy an interest and an outfit for the expedition. After a year's preparation in Spain and the West Indies, the expedition sailed from Havana, and on the zoth of May, I539, landed at Tampa Bay.
Then began the wonderful march. It was more than four years from that time before the survivors returned to their friends in Cuba, and brought the first news of the expedition. During those years the Spaniards had laboriously fought their way through portions of what are now the states of Florida, Georgia, Alabama, Mississippi, Tennessee, Arkansas and Louisiana. They worked westward, until in the summer of $15+2$ they crossed the State of Mississippi from the southeast to the northwest corner, and there reached the great river, at about the thirty-fifth degree of latitude, or the boundary line of Mississippi and Tennessee. It was a marvel to them-the grandest stream of fresh water that their eyes had ever seen; and one of the party has recorded that "the river was more than half a league over, and very swift." A great cross was erected on the shore in token of the religion of the Spaniards. But toil and disappointments at last made De Soto fail. He died, and to prevent the Indians from knowing of it, and from desecrating the grave, at dead of night his body was lowered into the depths of the mighty river, and there it sunk from view forever. The remaining members of the party made their way home in the course of another year. 


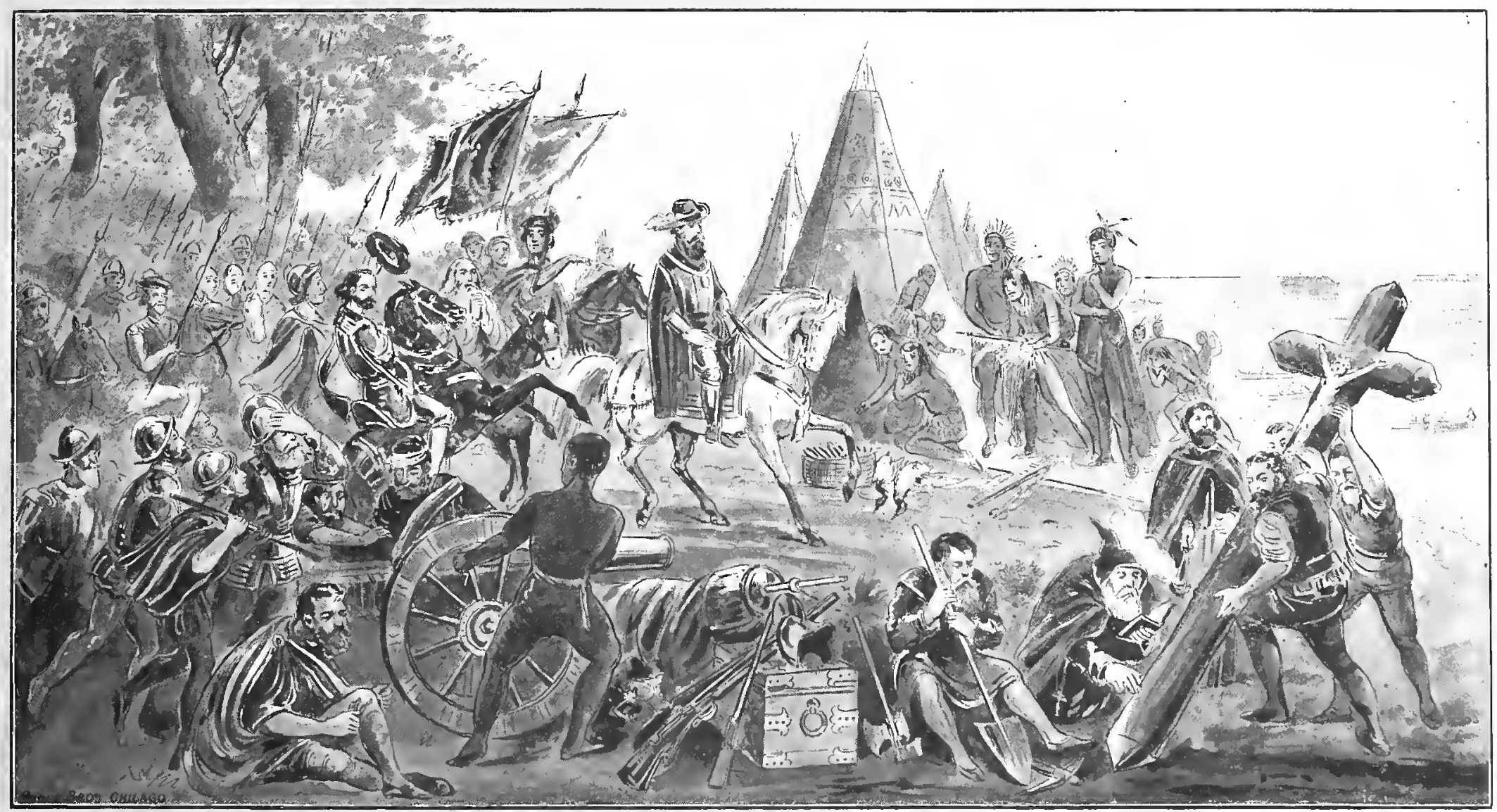

DE SOTO DISCOVERING THE MISSISSIPPI. 
AGRICULTURE.

THE great agricultural interests of the country are to be recognized in this Exposition on a grander scale than they have ever been before. The building provided for them is a triumph of beauty and art, and every advantage has been given to the department. Its chief is one of the best qualified of all connected with the Exposition. The building stands very near the shore of Lake Michigan. lts longest dimensions are east and west. For a single story structure, the design is bold and heroic. On either side of the main entrance are mammoth Corinthian pillars, fifty feet high and five feet in diameter. All through the main vestibule is statuary illustrative of the agricultural industry. Similar designs of an elaborate character are grouped about in all of the grand entrances. The corner pavilions are surmounted by domes 96 feet high, and above these, tower groups of statuary. The design of these domes is that of three female figures, of herculean proportions, supporting a mammoth globe. High above all, on the center dome, is poised the noted statue of Diana, from the Madison Square Garden, in New York, balanced so perfectly that, although it weighs several tons, it is yet a weather vane, and turns with the slightest breeze. To the southward of the Agricultural building is another spacious structure, designed for the use of the farmers and live-stock men of the country, to be used as an Assembly Hall. On the first floor is a bureau of information; committee and other rooms for different live-stock associations, and also large and handsomely equipped waiting-rooms. Broad stairways lead from the first floor into the assembly-room, which has a seating capacity of about one thousand. Granges, farmers' alliances and other rural organizations are provided for in this building. The assembly-room furnishes a place for lectures, which are delivered frequently by men prominent in their own line of work, embracing every interest connected with live-stock, agriculture and allied industries. A great advancement has been made since the Centennial at Philadelphia in all branches of farm work. Since that time the Department of Agriculture has been given a place in the President's cabinet; experimental stations in many regions have worked and prospered; irrigation, road improving, tree planting, and the beet-sugar industry have been attracting much attention, and now in this magnificent edifice are displayed the results of the advance in these and a thousand other branches of agricultural science. 

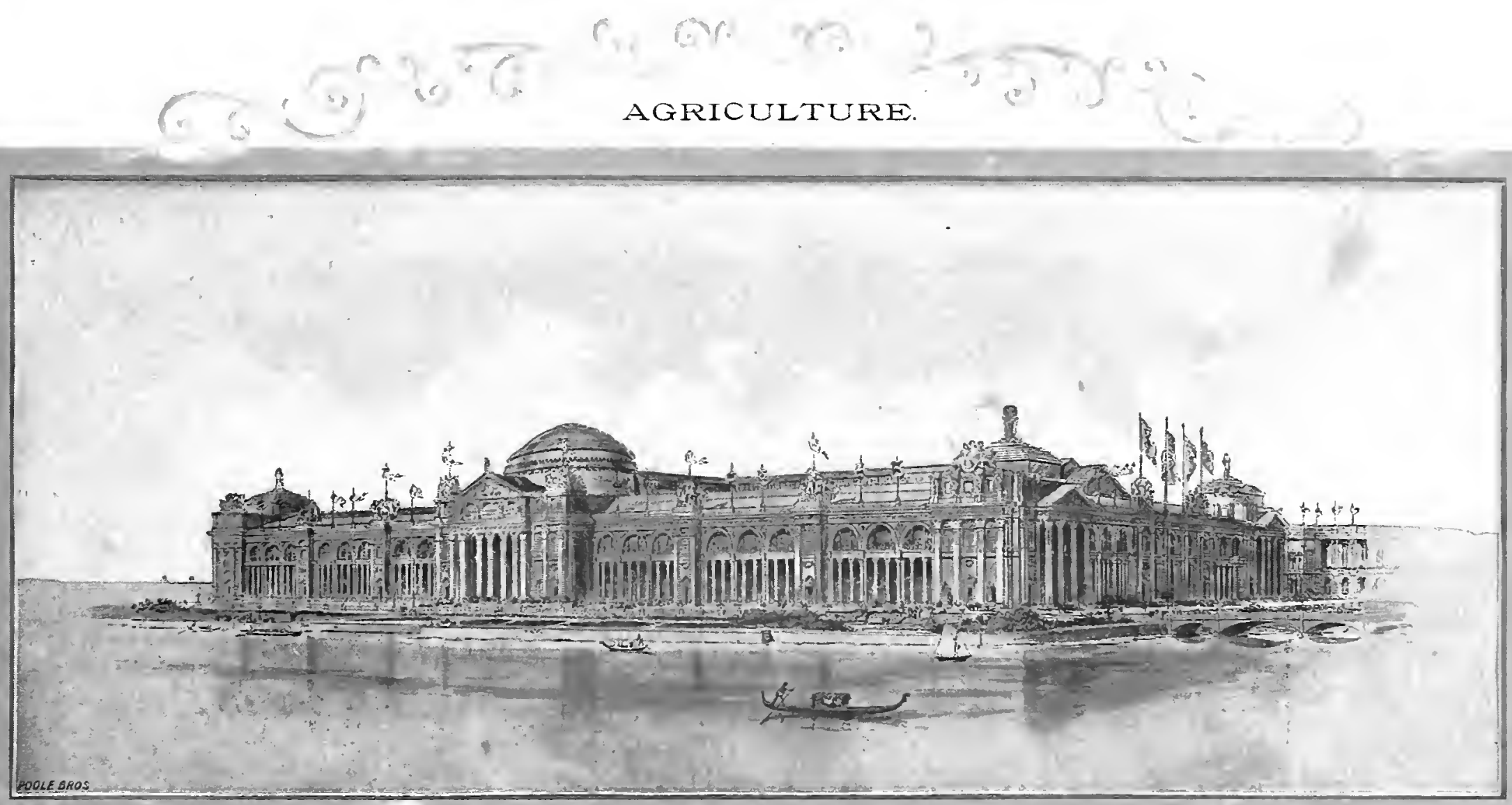

2. Total Area, Eighteen Acres. Cost, $\$ 620,000$. - (-) Dimensions, Main Building, $500 \times 800$ Feet. Annex, $300 \times 550$ Feet.

$$
50 \text { (5) Assembly Hall, etc., } 450 \times 500 \text { Feot. }
$$


A FTER the eventful voyage of Columbus which resulted in the discovery, it is doubtful if there is a single incident in American history which is so generally known to every American as the landing of the Pilgrim fathers. It has been immortalized in prose and verse, music and the drama, and in art. The theme is worthy the pen or the brush of a genius. It marked the consecration of this continent to freedom of conscience and worship, and resistance to the tyranny of an oppressive monarch. The colonists were originally from Scrooby, a village in Nottinghamshire, England, and had gone from there to Amsterdam and Leyden to secure that liberty for which they afterwards sought in America. Their worldly circumstances were not of the kind to make them happy in the Dutch cities, among strangers, so it was decided to secure a charter and go far across the sea to make for themselves a new home. Years of effort failed to induce the King of England to grant them such a charter as they required, so, at last, despairing of waiting any longer, they made up their minds to emigrate at all hazards. Two vessels, the Speedwell and the Mayflower, were procured, and on the $23 \mathrm{rd}$ of July, I620, they started from Delft-Haven to Southampton. The Speedwell proved unseaworthy, and a month was spent in fruitless efforts to get away, but at last, on the 6th of September, the Mayflower made a successful departure from Plymouth alone, carrying besides her crew, IO2 persons for the new colony. It was sixty-five days before they saw land again, and then only after a passage so rough that at times they expected to be lost. They sighted Cape Cod on the gth of November, and from that date till the middle of December, they cruised up and down the coast and sent out exploring parties to find the best place for a settlement. The landing of the Pilgrims on Plymouth Rock is of somewhat uncertain date. The date which we celebrate, December 22, is not right, and indeed it is difficult to say which is the worthier of the claims for the correct day. On Monday, December II, an exploring party of seventeen men landed on the Plymouth shore. That incident, which was by the new style chronology December 2I, is the one we erroneously celebrate on the 22nd. But it was not until Christmas day, or by new style, January 4, I62I, that the passengers from the ship, including the first of the women, really landed on Plymouth Rock. But the significance of the event will never be lost, though calendars fail to identify dates. 

THE PALACE OF ART.

$\mathrm{O}^{\mathrm{F}}$ all the beautifal structures of the "White City," the one which has received the most uniform praise, unanimous in fact, for the architectural merit of the design, is the one which is known as the Palace of Fine Arts. Leaders in the profession of architecture have united to give to it unstinted praise. It was planned by Charles B. Atwood, of New York, the designer-inchief of the Exposition. The exterior is of the pure Ionic style, the details having been carried out in the strictest and most academical manner. The proportion of the various divisions of the work was adapted from those of the famous temple of the Erectheum at Athens, but the composition of the general masses of the building was treated with freedom after the manner of the Academie des Beaux Arts. The walls are of brick and the roof construction is of iron, thus reducing to a minimum all risk of harm to the art treasures which are displayed there. In the colonnades and great entrance loggias are sculptured friezes after the manner of the frieze of the Parthenon at Athens. On the attic story of the great entrances are heroic statues in full relief against the pilasters, representing the arts and sciences. Between these, in the panels, are portrait busts of the masters of art, while crowning the dome of the main pavilion is a great winged figure following the fashion of the Victory of Samothrace. All about the exterior colomade are replicas in large size of the most celebrated antiques. The interior of the main pavilion contains a court Ioo feet wide, running north and south, and crossing one of the same dimensions, running east and west. All the sculptural display is arranged on the ground floor of these great courts. Around these courts run galleries, 24 feet above the floor and 20 feet wide, and lighted by great central skylights. Under these galleries, in alcoves, are displayed bas-reliefs and casts of architectural remains. In the gallery floor, on the walls and on cross screens are displayed all the architectural plans, the etchings, photographs and prints, which are shown in the building. The picture galleries are all arranged in the four angles of the building. They are 30 feet in height, and average $30 \times 60$ feet of floor space. In the annexes, the easterly pavilion is entirely occupied with the French collection, and the American section is in the angle of the main structure, adjoining. The westerly pavilion is occupied by several of the foreign peoples, who show smaller collections. Each annex has a central dome, about 50 feet in diameter. 


\section{ART}

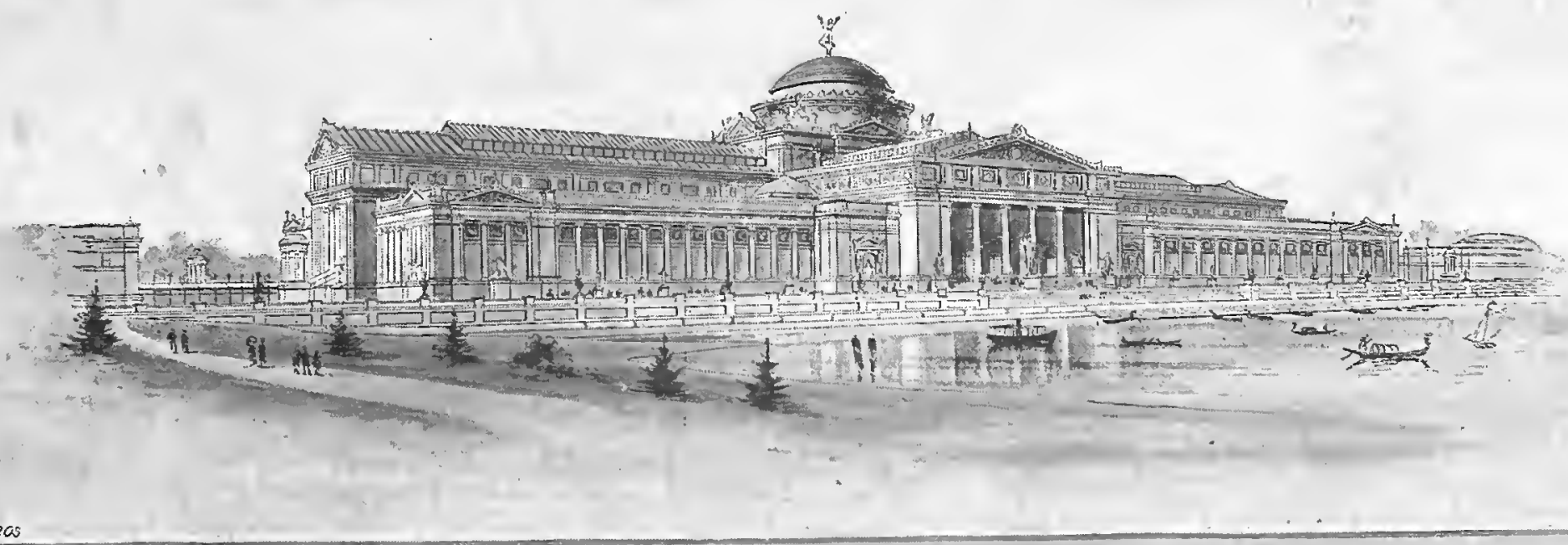

Total Area, Five Acres. Cost, $\$ 670,000$.

PLI The

- Colmensions, $320 \times 500$ Feet.

wo Annexes, $120 \times 200$ Feet. 
UR national life was brought into existence with the passage of the resolution by the Continental Congress that "These United Colonies are, and of right ought to be, free and independent States; that they are absolved from all allegiance to the British Crown, and that all political connection between them and the State of Great Britain is, and ought to be, totally dissolved." That resolution was passed July 2, 1776. Nothing was done with haste that might be considered unseemly in such an event. On the 7 th of June, Richard Henry Lee had offered resolutions before the Continental Congress that a plan of confederation should be formed and independence declared. There was full and free discussion of the plan, and as it became evident that the resolution would be passed, that no time might be lost, a committee was formed to draft a declaration. The members were Thomas Jefferson, John Adams, Benjamin Franklin, Roger Sherman and R. R. Livingston. The declaration was reported, and after discussion and postponement it was passed, every colony voting in its favor except New York, whose delegates, being still uninstructed, did not vote at all. The accompanying view of the signing is taken from a noted painting. It was there that John Hancock wrote his name, as he said," so large that King George could read it without his spectacles;" and it was there that another of the patriots said, "If we do not all hang together, we will most surely all hang separately."

Of the event itself Adams said in a letter to his wife: "But the day is past. The second day of July, 1776 , will be the most memorable day in the history of America. 1 am apt to believe that it will be celebrated by succeeding generations as the great anniversary festival. It ought to be commemorated as the day of deliverance by solemm acts of devotion to God Almighty. It ought to be solemnized with pomp and parade, with shows, games, sports, guns, bells, bonfires and illuminations, from one end of this continent to the other, from this time forward, forevermore." Thus far the event has been celebrated as Adams said it should be, but on the wrong day; for the resolution passed on the 2 nd was the formal declaration of independence, while the one of the $4^{\text {th }}$ was the declarations of the reasons for establishing an independent government. The passing and signing of the Declaration of Independence formed an epochal event in the history of this nation, the influence of which is the most constant in our lives of anything in all history. Its importance cannot be exaggerated. 


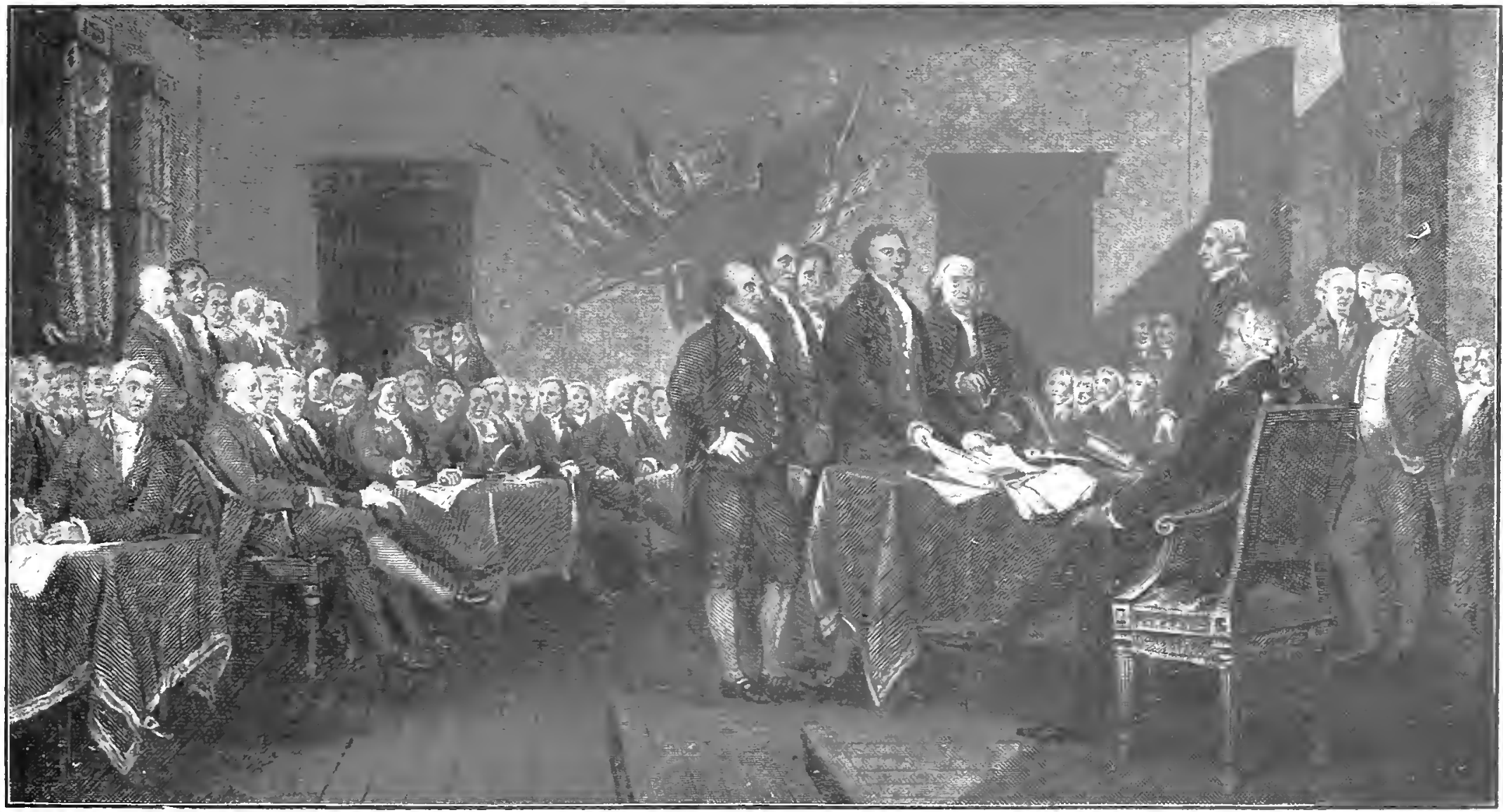

SIGNING THE DECLARATION OF INDEPENDENCE. 


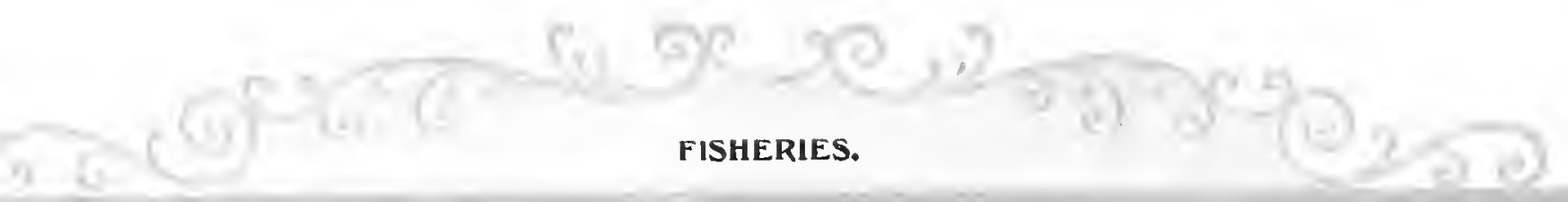

$\mathrm{E}^{\mathrm{A}}$

$\mathrm{ACH}$ of the Exposition structures seems to be in some one thing the greatest of all. The distinguishing characteristic of the building which is devoted to the display of fish and fisheries, is its unconventionalism, its oddity, if you please. It is safe to say that its design will attract the attention of more of the lay visitors during the Fair than will any of its competitors. This does not mean that it is lacking in architectural dignity and merit, for its severest critics in the profession have been the most liberal in their compliments of its real poetry of design. It is situated on a curved peninsula opposite the Government building, from which it is separated by the lagoon. The structure follows the curve of the peninsula in its plan. It is composed of three parts: a main building and two annexes, the latter joined to the former, one at each extremity, by a curved arcade. The main building is provided with two great entrances in the center of the long sides. These entrances are by pavilions 102 feet long, projecting beyond the line of the main building and flanked at either corner by circular towers. The great pediment over the south entrance is filled with sculpture, the subject being a scene of whale-fishing. The angles are surmounted by statues representing fishers casting the spear, throwing the handline, and holding the finny prey. The type which the building copies is the Spanish Romanesque, and all the details are worked out in a realistic way, after marine forms. The pillars and arches of the colonnades of the bulding, for instance, are richly and ingeniously decked with turtles, crabs, lobsters and fish of various kinds, and this is done so that the effect is uniformly beautiful. The delicate open work of the gallery displays thousands of varied groupings of fish. Fish culture in all its branches is displayed here. Great aquariums of fresh and salt water, some holding 27,000 gallons, show living fish of every kind possible to secure. Fossil forms of marine life, strange things so rare as to be almost extinct, all are shown here. There are also interesting exhibits of the fisheries industries the sardine of France, the cod of Newfoundland, and the salmon of Washington, all being exhibited from start to finish of their commercial career. And in addition to all these things, there are exhaustive displays of all kinds of anglers' implements from every country; and on the banks of the lagoon which faces the building, they are all put in operation for the pleasure of the visitor. 

THE DEVELOPMENT OF STEAM NAVIGATION.

CEAN greyhounds to-day steam from New York to Liverpool in six days, and nothing is thought of it. Columbus sailed for seventy days from Palos pier before the sight of land gladdened his eyes. The enormous developinent of the art of navigation has, in great degree, been American. There was a time when the clipper ships of this country carried the flag to every part of the globe; when American whalers covered the north seas, and when American sailors were the best in the world. And we yet hope to see a revival of those days when America was supreme in the carrying trade of the world. Within a few months we have seen the transfer of one of the grandest steamers on the seas from the British to the American flag. It is the New York, the picture of which is on an opposite page. From that vessel to the first steamer of Robert Fulton, the inventor, is a long look backward. They were American inventors who devoted their attention to the efforts to drive boats by steam; and the experiments were discouraged by almost everyone. At the beginning of the century, the most noted engineer in the country expressed his regret that American inventors waste so much time in futile efforts to drive boats by steam, instead of turning their attention to the improvement of the steam engine for its work on land. The first successful experiment was made in this country. In the summer of 1807 , a boat called the Clermont made the trip from New York to Albany in thirty-two hours, and the return trip in thirty. This was at the rate of five miles an hour, and won many to believe in the success of the affair; but it was not until I8I2 that a steamboat navigated the waters of the Ohio.

In 1818, there were regular passenger boats on Lake Erie, and the next year was the date of the first trans-Atlantic passage. Moses Rogers, of New London, Connecticut, in command of the ship Savannah, of 300 tons, sailed and steamed - for he used both sails and wheels - from New York to Savannah, and thence to Liverpool. The voyage across the ocean was made in twentyfive days. The Savannah had been built in New York, and her engines were made at Morristown, New Jersey. The voyage of the ship and its return to America attracted little attention, and it was not repeated for twenty years. Then came an immense awakening of industry, and from that time the growth of the steam traffic of the world has made rapid strides. Ocean steamers of to-day are floating palaces, and an ocean voyage has not as much terror for the traveler now as a twentymile journey a hundred years ago. 


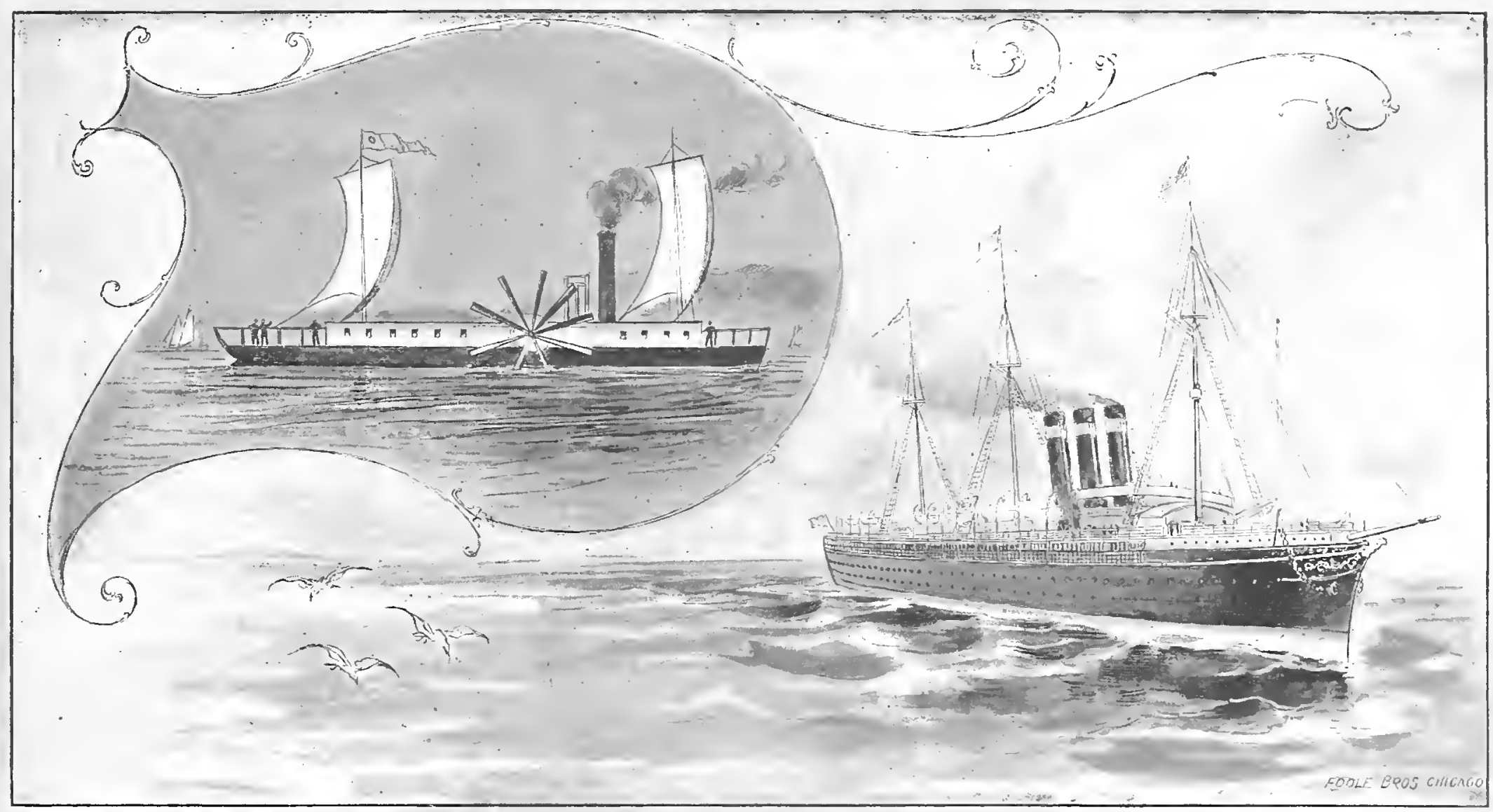

THE CLERMONT.

THE NEW YORK. 
FXCEPT the Department of the Navy, all the great departments of the United States display their work and exhibits in the U.S. Government building. That great department, which of late years the country is glad to see becoming a reality, very properly shows its exhibit in a structure built to represent a genuine battleship. Millions of Americans who live far within the interior of the country have never seen a battleship, and this opportunity to see the perfect representation of one is a great pleasure to them. This imitation battleship of 1893 is erected on piling on the lake front, in the northeast portion of Jackson Park, adjoining the space occupied by the British government. The structure has all the fittings that belong to the actual ship, such as guns, turrets, torpedo tubes, torpedo nets and booms, with boats, anchors, chain cables, davits, awnings, deck fittings, etc., together with all appliances for working the same. Officers, seamen, mechanics and marines are detailed by the Navy Department during the Exposition, and the discipline and mode of life on our naval vessels are completely shown. The detail of men, however, is not so great as on the actual ship. The crew give certain drills, especially boat, torpedo and gun drills, as on a vessel of war. The dimensions are the same as are those of the actual battleship. From the water line to the top of the main deck is twelve feet. Centrally placed on this deck is a superstructure eight feet high, with a hammock berthing on the same seven feet high, and above these are the bridge, charthouse and the boats. At the forward end of the superstructure is a cone-shaped tower called the "military mast," near the top of which are placed two circular "tops" as receptacles for sharpshooters. Rapid firing guns are placed in each of these tops. The height from the water line to the top of this military mast is seventy-six feet, and above this is placed the flagstaff for signaling. The battery mounted comprises four I3-inch, breech-loading, rifle cannon; eight 8-inch, breech-loading, rifle cannon; four 6-inch, breech-loading, rifle cannon; twenty 6pounder, rapid-firing guns; six I-pound, rapid-firing guns; two Gatling guns, and six torpedo tubes or torpedo guns. All of these are placed and mounted as in the real battleship. On the starboard side of the ship is seen the torpedo protection net, stretching the entire length of the vessel. Steam launches and cutters ride at the booms, and all the outward appearance of the real ship of war is imitated. The unusual character of the exhibit makes it a favorite with all. 


\section{6.}

\section{-}

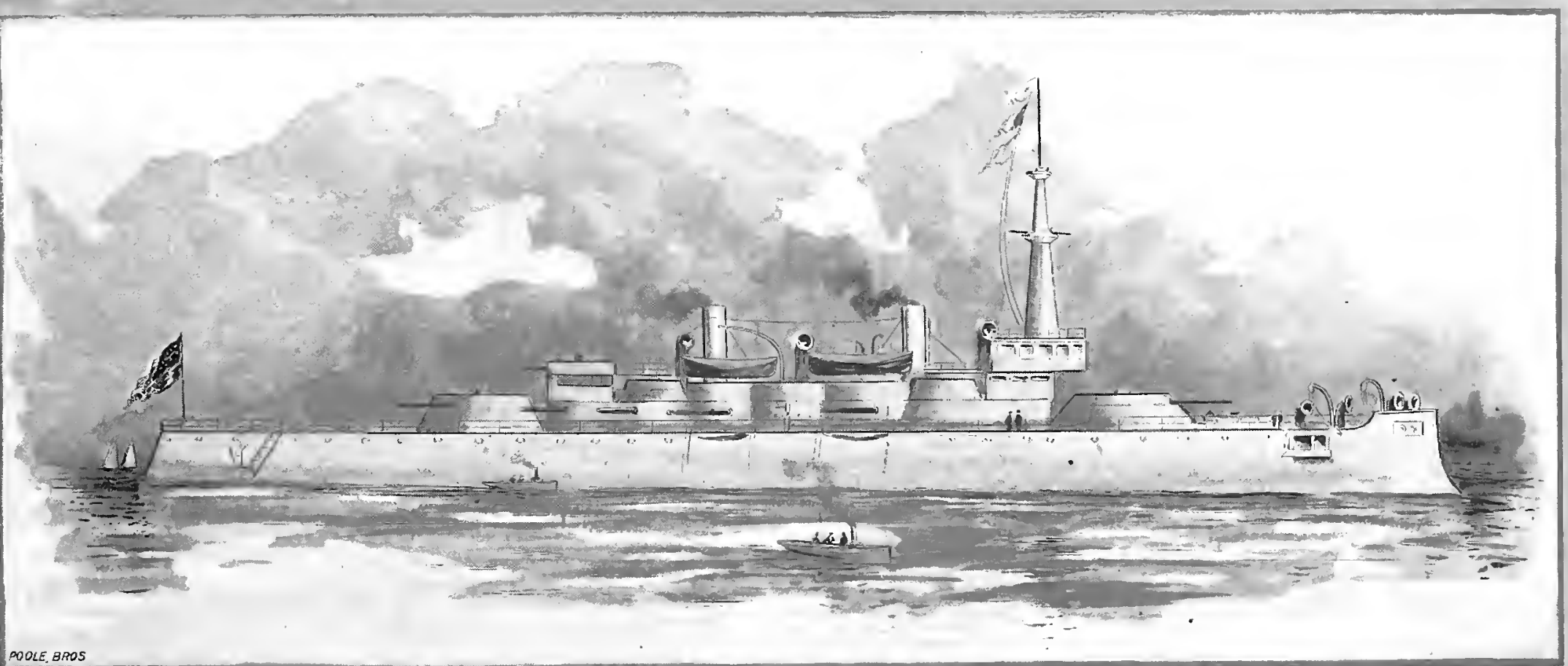

POOLE BROS

$$
\left(\begin{array}{ll}
\text { Length, } 348 \text { Feet. Width, 69I/4 Feet. } \\
\text { (Size of actual Battleship.) }
\end{array}\right.
$$


THERE are some expressions made by men in the heat of battle or victory that have come down through history from many years ago, and that by the very condensation of their patriotism will ever be famous. Who will forget "Don't give up the ship;" or, "If any man attempts to haul down the American flag, shoot him on the spot;" or, "I propose to fight it out on this line if it takes all summer?" And so of all of them, that which was sent from the scene of battle depicted on the opposite page is one of the most inspiring and one of the most notable. Casar said, "Veni, vidi, vici;" Wellington telegraphed, "Cantharides;" our own Commodore Perry announced a victory in a dispatch which he sent to General Harrison that was almost as terse. The circumstances were these: War with England was in progress, and the land campaigns of the year 1813 had not been favorable to our arms. It was felt necessary that some victory should be won to revive the hope that was at times almost discouraged. Perry was the man to win the victory. He was placed in command of a squadron at Presq' Isle, now Erie, early in June, and by August was afloat with ten vessels, carrying fifty-five guns, with which to go in search of the British fleet of six vessels with sixty-five guns.
On the tenth of September, while at anchor in Put-in-Bay, the enemy was seen approaching, and Perry made ready for battle. In the earlier hours of the struggle, the fortune of war seemed to be with the enemy. They concentrated their fire on the American flag-ship, Lawrence, with terrible effect, and soon reduced her to a wreck. Perry made the best of his way to the Niagara, and by great effort closed up his line. The tide of battle suddenly turned. In attempting to form a new line of battle the British squadron was thrown into some confusion, and the Niagara, favored by a sudden breeze, sailed through it, delivering broadsides right and left. Then, luffing across their bows, she raked two or three of them, while the small vessels came up and poured in grape and canister. Twenty minutes of this work decided the contest, and the whole British fleet surrendered. Perry's dispatch to General Harrison simply said: "We have met the enemy, and they are ours: two ships, two brigs, one schooner and one sloop!"

This glowing success revived the drooping fortunes and spirits of the Americans, and with renewed energy the war was prosecuted until it resulted in victory and peace. 


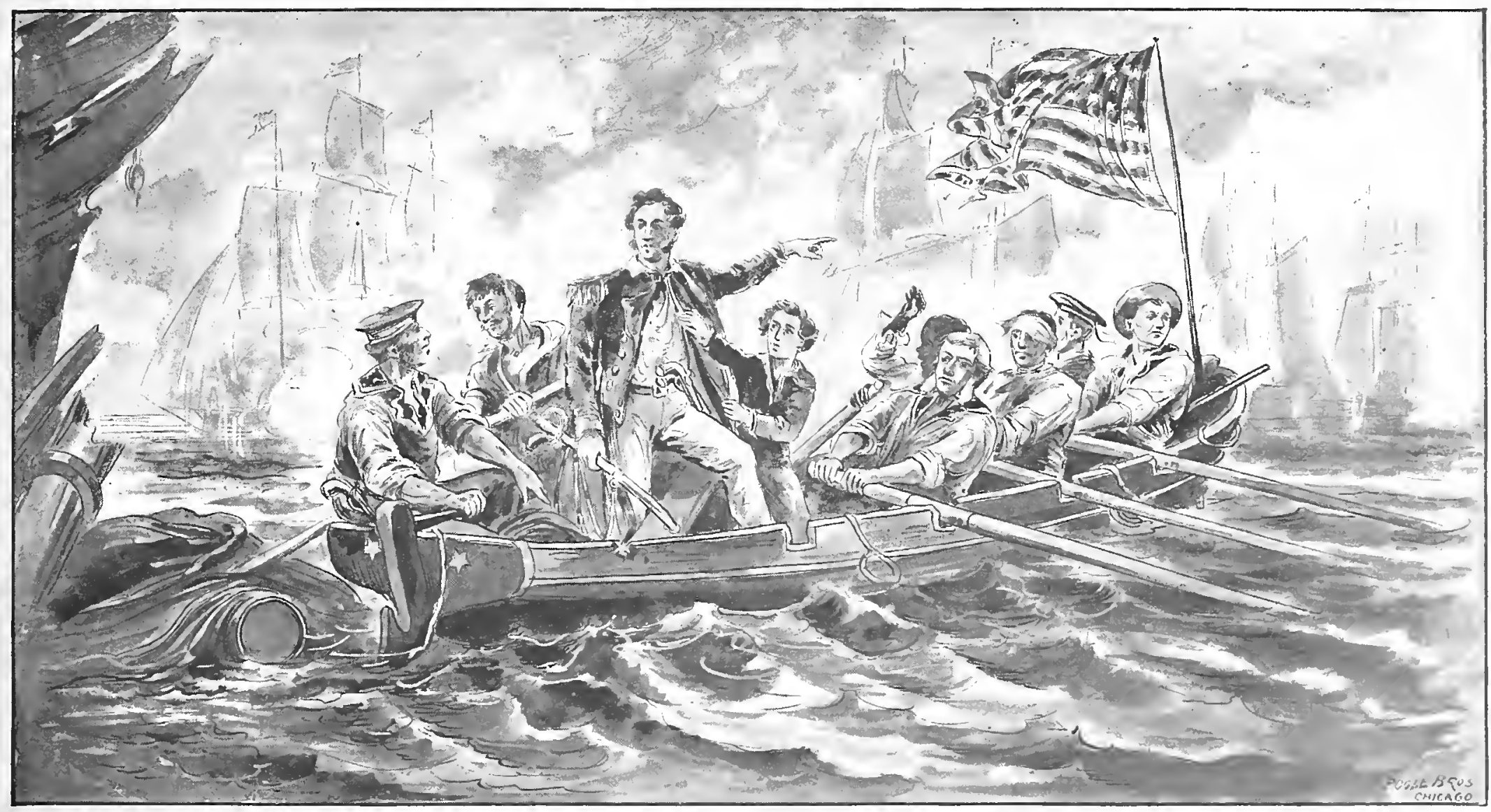

PERRY AT LAKE ERIE.

"We have met the enemy and they are ours," etc. 
SEVERAL of the great structures of the World's Fair are notable as being the first ever erected at any International Exposition for the purposes for which they are used. One of these is the building for the exhibit of Mlines and Mining. As this nation is the most fruitful in minerals of all lands, it is appropriate that one of the finest of the Exposition structures should be devoted to this purpose, and that this should be the first time when such attention is paid to the great mining industries. The building is located at the south end of the western lagoon, and between the buildings of Transportation and Electricity. Its architecture has its inspiration in early Italian renaissance, with which sufficient liberty is taken to invest the building with the animation that should characterize a great general exposition. There is a decided French spirit manifested in the exterior design, but it is kept well subordinated. In plan it is simple and straightforward. On the ground floor are spacious vestibules, restaurants, toilet rooms, etc., in addition to the great main exhibit hall. The galleries are 60 feet wide and 25 feet above the ground floor, and are lighted on the sides by large windows, and from above by a high clere. story, extending around the building. The allegorical figure over the main doorway is eminently fitting as a classical representation of the great industry, to which the edifice is dedicated. Mining is represented as a colossal, half-reclining female figure, in Greek drapery, holding aloft in one hand a lamp to guide the miner, and in the other a pick. The figure was designed by Richard W. Bock. This building was the first of the Exposition structures to be begun, and the first finished. It has additional interest from the fact that it is the first building ever constructed in which the roof is supported by cantilever trusses. In that it marks an era in great roof building. In no other department of the Fair is shown a greater diversity of exhibits than in the Mines and Mining building. Not only is there a dazzling array of diamonds, opals, emeralds and other gems, and of the precious metals, but a most extensive collection of iron, copper, lead, and other ores and of their products; of coal, granite, marble and sandstones; of soils, salt and petroleum, and indeed of everything useful or beautiful produced from the mineral kingdom. The exhibition of mineral resources and products, not only of this country as a whole, but of each State and section, as well as of foreign countries, is of the most complete and representative description. 


\section{MINING.}

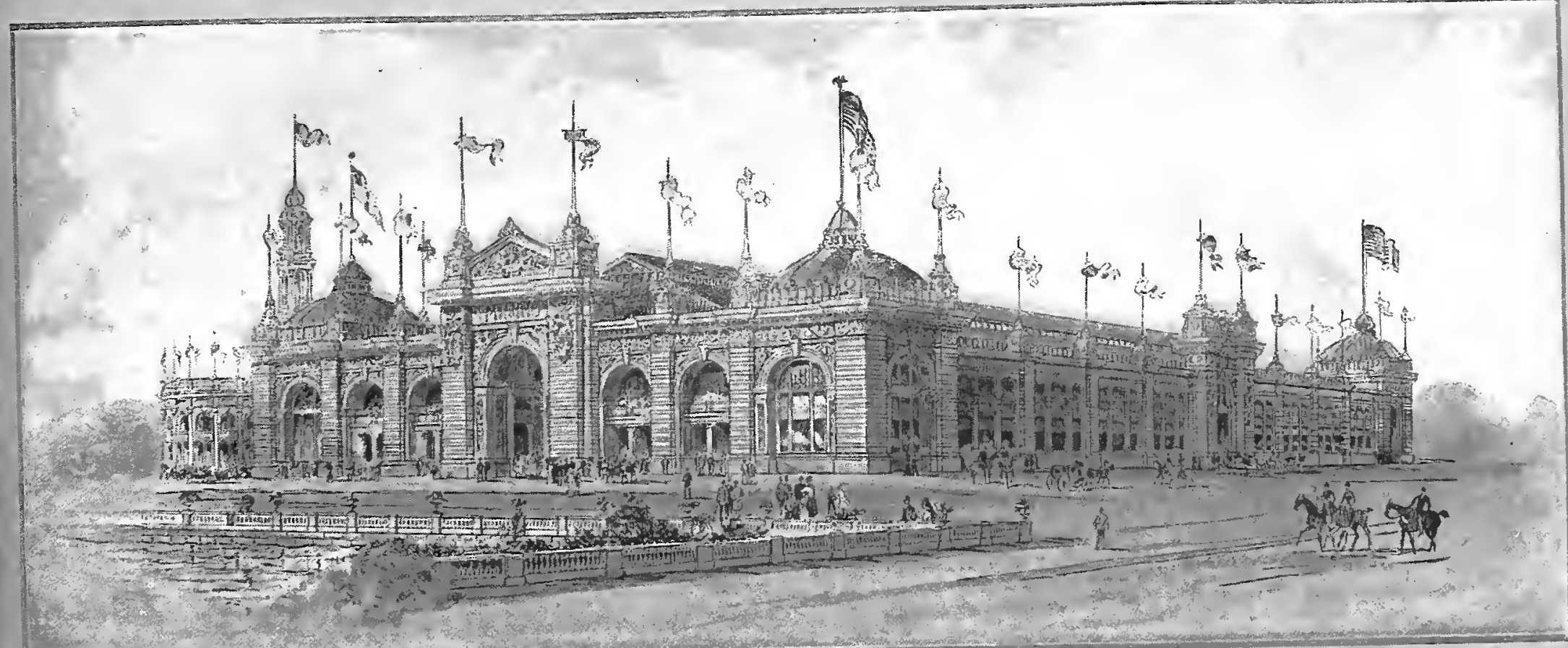

Area, Nearly Six Acres, Cost, $\$ 265,000$

Dimensions, $350 \times 700$ Feet. 
THE DEVELOPMENT OF RAILWAY SYSTEMS.

THE minds of the younger generation of Americans, cannot conceive of a country without railroads, so intimately are the thousand of miles of the "iron traits" connected with all the development and all the prosperity and later history of the country. And yet the life of the railroad is still young, and its history can be written in brief. The first timid experiment in railroads was a tranway in Quincy, Mass., built in 1826 . It was run by horses, but was the germ of a mighty movement in this country. The first railway in America for passengers and traffic, the Baltinore \& Ohio, was chartered by the Maryland Legislature in March, I827. The capital stock at first was only a half a million dollars, and a portion of it was subscribed by the State, and by the city of Baltimore. Horses were its motive power even after sixty-five miles of the road were built. But in 1829, Peter Cooper of New York, built a locomotive in Baltimore which weighed one ton and made eighteen miles an hour on a trial trip to Ellicott's Mills. In 1830 there were twentythree miles of railway in the United States, which was increased the next year to ninety-five, in 1835 to Iog8, and five years later t) nearly 3,000. That is an index of the growth that has characterized the same industry ever since the first.
The views on the opposite page are the pictorial representation of the strongest of contrasts - that between the locomotive and train of the first successful American railway, and one of the magnificent trains of the Wabash in I893. One is the beginning, the other is the culmination of luxurious rapid travel. From electric headlight to rear platform, these Wabash trains are a compendium of all that is comfortable and safe in railway appliances. The locomotives are of the best modern construction, their baggage facilities are noted for the perfection of their arrangements for the convenience of travelers; finest smoking cars and day coaches, with free reclining chair cars are to be found on all through trains; while the dining car service has won a reputation that is remarkable for its elegant meals and service, and after a luxurious dinner, and a pleasant smoke, the sleeping car invites to perfect rest and repose. The road-bed of this line is of the best; the grades and curves are light; the lines direct; the time tables schedule fast time, and what is better, the schedule is adhered to; so what else can he desired by the most carping tourist? The universal satisfaction which travelers feel towards the road, is testified by the ever increasing traffic that comes to it. 


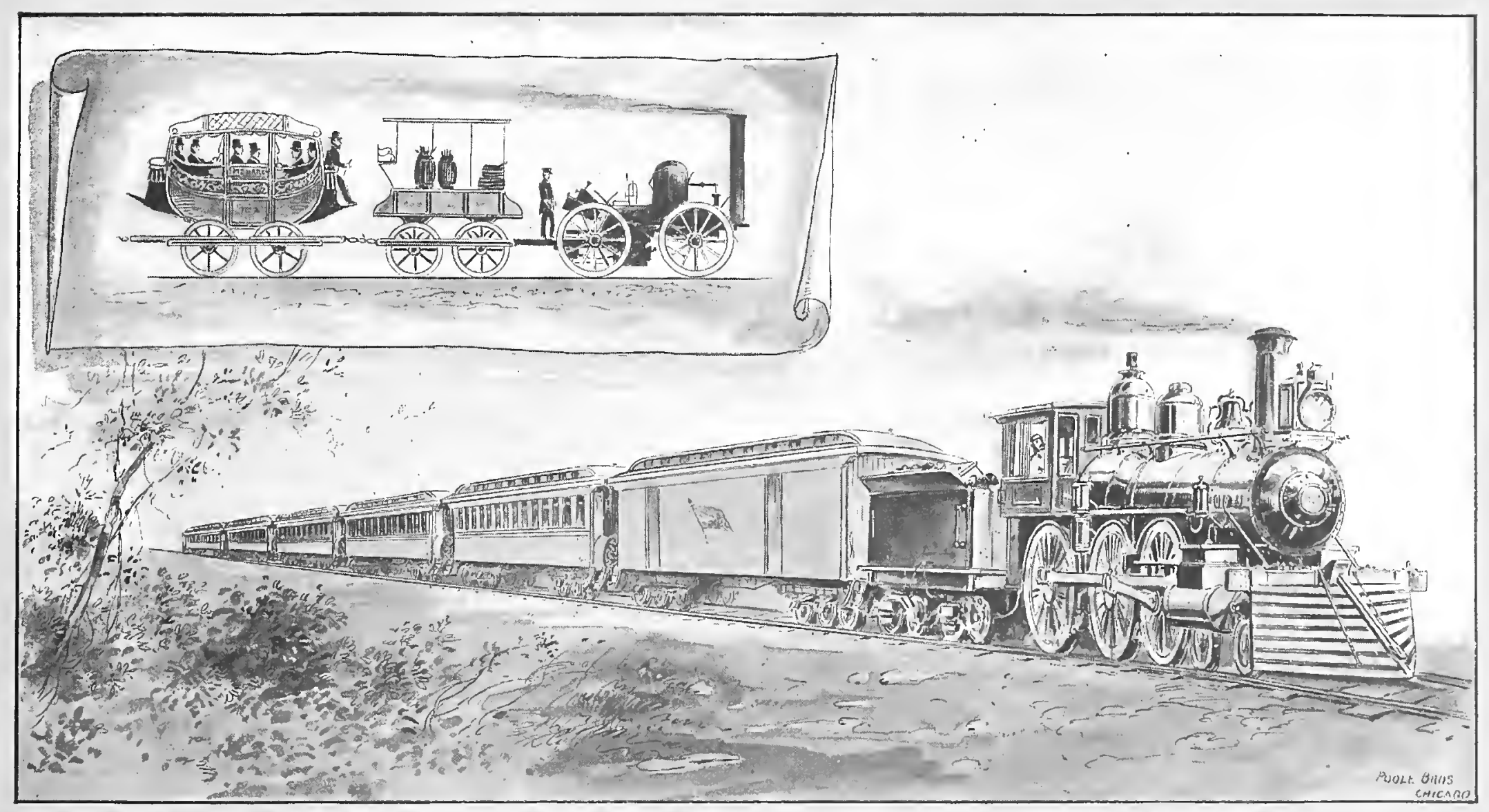

THE FIRST RAILROAD TRAIN IN AMERICA, 1827.

THE WABASH, 1893. 
THE complete history of transportation, two notable contrasts of which are exemplified on the previous page, is illustrated in the great building called Transportation, another of the "first ones" which are so numerous in this Exposition. Of the building itself, the leading architectural characteristics disclose simplicity of design, harmonious structural effects, and dignity of massive proportion, relieved by richly ornate details. At the center it is surmounted by a cupola 165 feet high, which affords an extensive view of grounds, lake, and surrounding country. This point of observation is reached by eight elevators (the only depariment building thus provided), which of themselves properly form a part of the transportation exhibits, and are run for the use of the public. The central court is abundantly lighted from a clerestory above. The grand portal on the east front, facing the lagoon, consists of a series of receding arches, entirely overlaid with gold leaf. It has been termed "The Golden Door," but this hardly conveys an adequate idea of its splendor. The exterior arch overhead is ornamented with striking allegorical figures and groups in bas-relief. On one side appears in panel an original study in ancient transportation, and on the other the palatial accessories of modern railway travel. With this building is an annex, measuring 425 by 900 feet, and having an area of nearly nine acres. The exhibit of the history of transportation begins with velicles as rude as the dugout of the savage and the chair on which the guides of the Andes transport travelers on their backs. It is crowned with the marvels of modern railroads, the best equipment that great lines like the Wabash can boast. As the chief of the department is fond of saying, "It contains everything from a tin toy wagon to a mogul locomctive." of course, transportation on land and sea are given equal prominence. Rafts, log boats, dugouts, skin canoes, bark canoes, gondolas, sail boats, the caravels of Columbus, the racing yacht and the clipper ship, the modern transatlantic liner, all are shown either by model or in full size. And for land transportation we have the sedan chair, the elephant howdah, carts, wagons and stage-coaches from every land, the earliest development of railroads, and the modein locomotive, dining car and palace car such as the Wabash uses. Bicycles, balloons and all such things are fully represented. This great structure is painted a Venetian red, and is the only variation in the color of the large buildings in the "White City." 


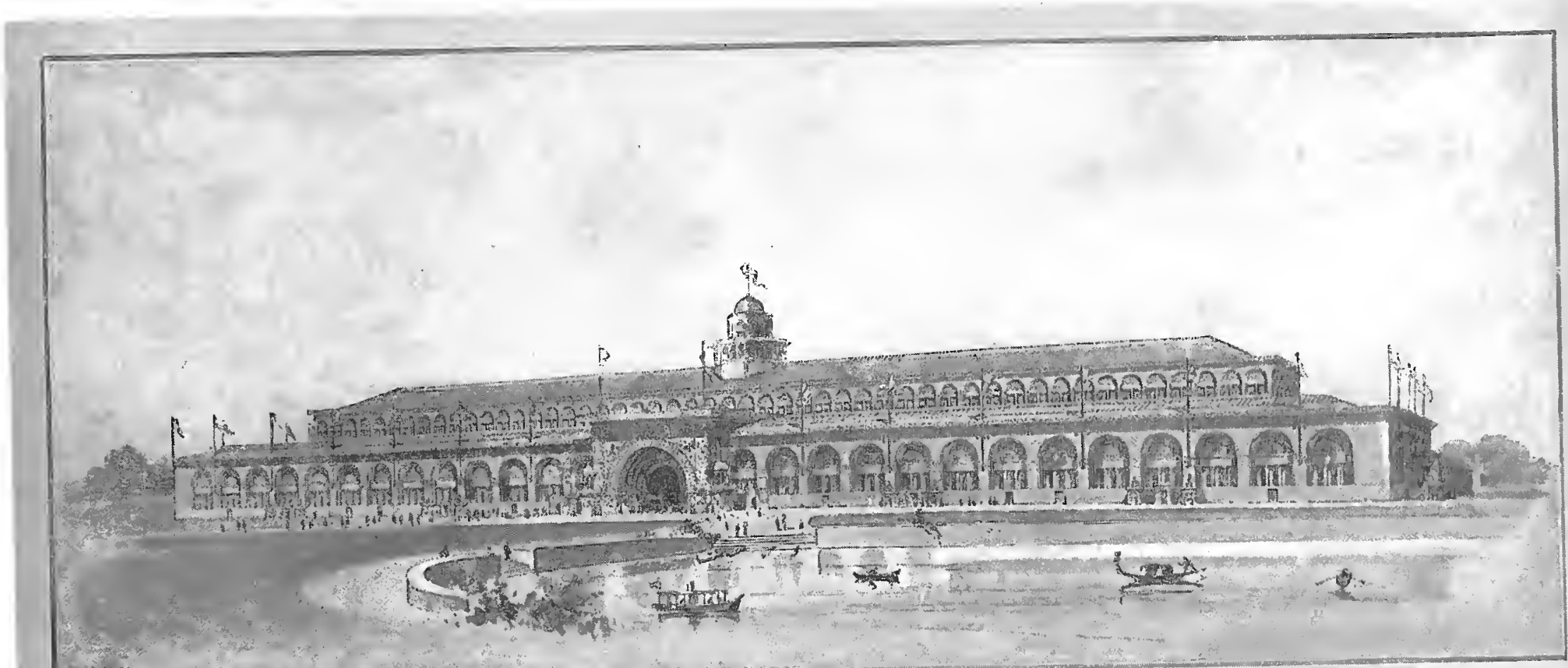

Area, Six Acres, Cost, $\$ 300,000$

Dimensions, $250 \times 960$ Feet. 


\section{ELECTRICITY.}

SIDE BY SIDE with the advance of steam has been the advance of electricity. Now it is forging ahead. Nen who have done what wizards might be proud to do, have snatched the lightning from the clouds, have chained and harnessed it, have tamed it and called it servant! lt is an age of wonders, and no longer is the world amazed when something is done that but a few centuries ago would have sent the doer to a witch's doom. There have been epochs in the application of the powers of electricity. One was when Benjamin Franklin, printer, philosopher, statesman and scientist, sailed his silken kite into the air and toying with the thunders of heaven, proved ly a flash from a key the identity of lightning and electricity. The second epoch was the time when communications were first flashed over a wire by means of the same subtile fluid. In I8to S. F. B. Norse, of New York, obtained a patent for an apparatus by which an instantaneous communication could he carried over wires for any distance by electricity. Four years afterward an experimental line was erected between Baltimore and Washington, and its success put the invention into immediate practical use. The first message sent over the wire was "What hath God wrought!"
The third of the great milestones that mark the progress of electrical science, was the successful laying of the Atlantic cable. Cyrus IV. Field had devoted several years of effort and much money to the advancement of the plan for a cable from America to England, and though the first suggestion was overwhelmed with sneers, it was an ultimate success. In i866 a strong and flexible cable was shipped on board the Great Eastern, which, after a prosperous vovage, arrived at Heart's Content, Newfoundland. It then returned to the mid-Atlantic, where the end of the cable which had been laid in 1865 was grappled and a splice was made. There are now several across the Atlantic, and others to almost every country on the globe. Now, of later years, the inventions in the science of electricity have multiplied so fast that one can scarcely follow them. We have the incandescent and arc light, the telephone, the phonograph, and many of less importance but no less interest. Inventors, of whom Edison is the most famous, are keeping their laboratories busy in the search for new marvels. It is promised by them that the World's Fair shall be a culmination of everything that is wonlerfu] in the realm of captured lightning. 


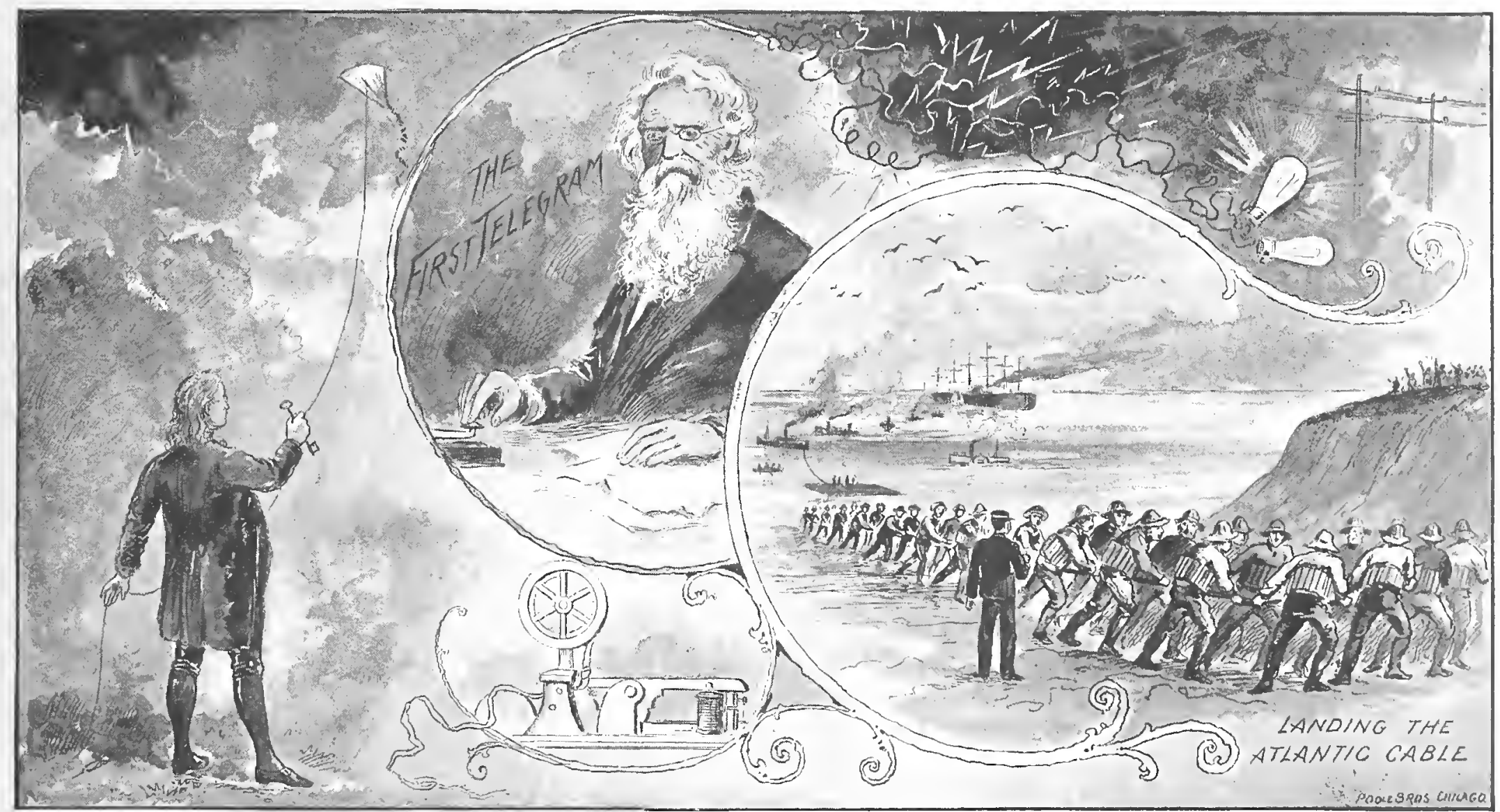

ELECTRICITY. 
THE ELECTRICITY BUILDING.

T $T$ has been the idea of the Exposition management to make of the whole Fair a wonclerful exemplification of the advance of electricity. With that in view the zoo acres of Jackson Park display at every turn some portion of what might be considered the electrical exhibit. But the building specially devoted to this display, containing with its galleries nine acres of floor space, is the Nlecca for more visitors than any other of the great structures. Practical appliances in electricity were almost introduced to the world at the Philadelphia Centennial, and the greatest portion of the advance $i n$ invention of fine electrical instruments of all kinds has been made in the seventeen years since then. Consequently the world is less familiar with that science and more interested to learn of it than of any other of the great departments, interesting as they all are. The exterior walls of the building are composed of a continuous Corinthian order of pilasters, supporting a full entablature and resting on a stylubate. At each of the four corners of the builling is a pavilion, above which rises a light open tower or spire, I6g feet high. Intermediate between these corner parilions and the central pavilions on the west and east sides is a subordinate pavilion bearing a low, square dome upon an open lantern. The building has an open portico extending along the whole of the south façade, the lower, or Ionic, order forming an open screen in front of it. Richness is a characteristic of the building. The pediments, friezes, panels and spandrels have received a decoration of figures in relief, the general tendency of which is to illustrate the purposes of the building. The appearance of the exterior of the building is that of marble, but the walls of the hemicycle and of the various porticos and loggia are highly enriched with color, the pilasters in these places being decorated with scagliola and the capitals with effects in bronze. A great statue of Benjamin Franklin, by the sculptor Carl Rohl-Smith, stands in front of the entrance to the building. A dozen great firms which manufacture and sell electrical apparatus have vied with each other to contest for supremacy of magnificence in their exhibits here. Hundreds of thousands of incandescent lights are placed harmoniously about the grounds. Every system of electric lighting is shown. The long distance transmission of power is shown in the highest developed state. Electric railways of all systems are provided. There are weeks of sightseeing for the visitor in this building, if he has the time to spend. 


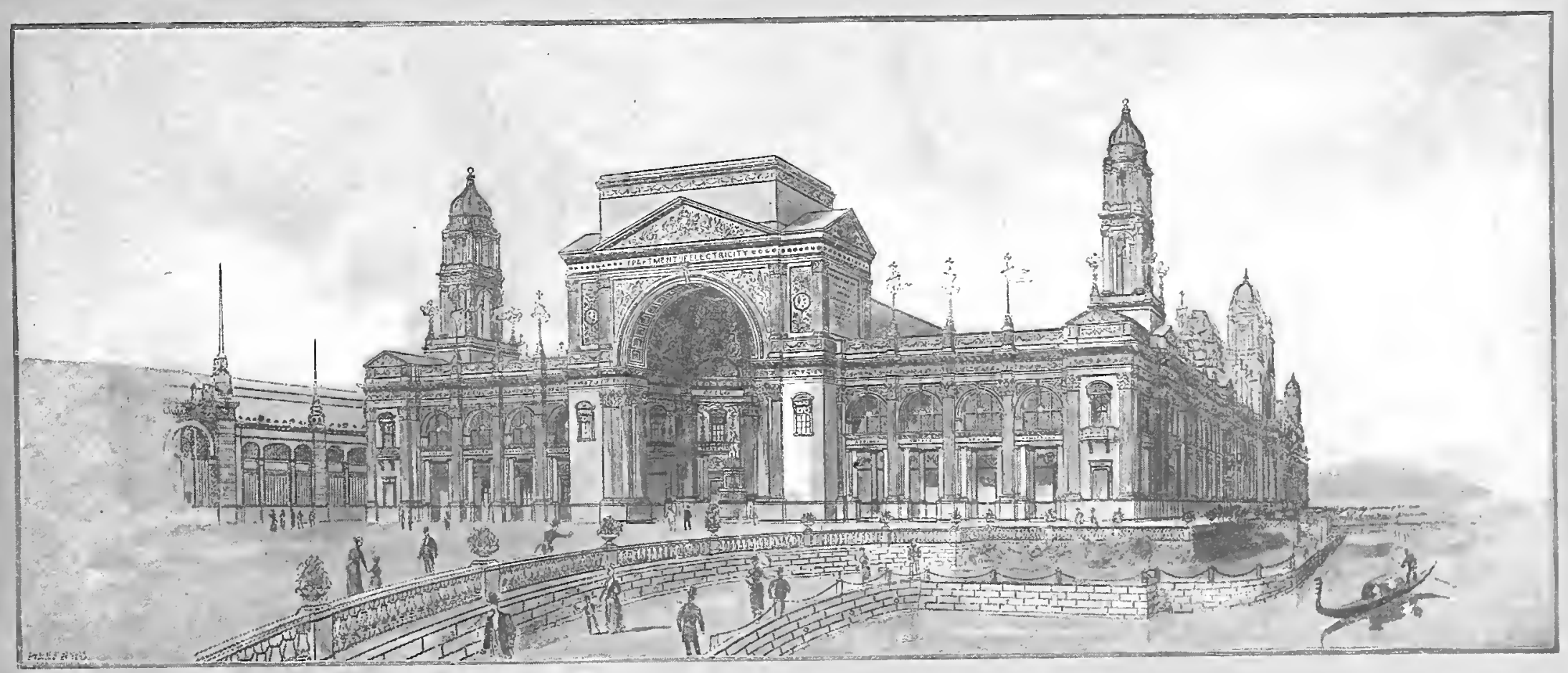


MEXICO and the United States to-day are sister republics. Once they were enemies and at war. As in every other war of our history, in this one there was a strong peace party, who condemned the declaration of war and the motives which they claimed lead to the commencement of hostilities. But in spite of the accusations of political influence, the war was fought to its conclusion - an overwhelning victory for the troops of the United States. The two great commanders who nuade fame during this war were Zachary Taylor and Winfield Scott. The first engagements of the fight were those while the army was under the command of Taylor. But later the Government at Washington indicated that it considered his manner of conducting the war too conciliatory, and so General Scott was sent to take chief command. Under Taylor, among more noted battles, had been fought those of Resaca de la Palma, Monterey and others. Col. Phillip Kearney, Gen. John C. Fremont and Commodore Stockton conducted brilliant operations in the far WVest, California and New Mexico. Scott took command in January, 18.7 , and without great delay fought the battle of Buena Vista. Then followed the siege and capture of Vera Cruz, and the army hegan its march towards the City of Mexico. The capital was two hundred miles distant, but Scott started for it as soon as he received the necessary supplies. Cerro Gordo was the first battle that interrupted him. At Contreras he was again intercepted, and another battle followed. Immediately after came the battle of Cherubusco. Then in rapid succession came the battle of Molino del Rey and the siege and capture of the castle at Chapultepec. The attack on the castle was made on September 13, and after a terrible figlt it was taken. The enemy gave way everywhere and the Americans pursued them into the city. Night fell, but the citadel was yet unconquered. The Mexicans held a council of war and decided to withdraw the army from the city, liberate the convicts, arm them, and urge everyone to fight from the house tops. So when morning dawned the Americans found that the army of the enemy was gone, but in its place were gangs of convicts, deserters, robbers and thugs, fighting from the house-tops by hurling paving stones down on the passers-by. Artillery was turned upon the houses, and the desperate people soon submitted. By the $15 \mathrm{th}$ of September, 18.18, the city was quiet and in the possession of the Americans. Then came the treaty which ended the war. There had not been an American defeat of any importance. 


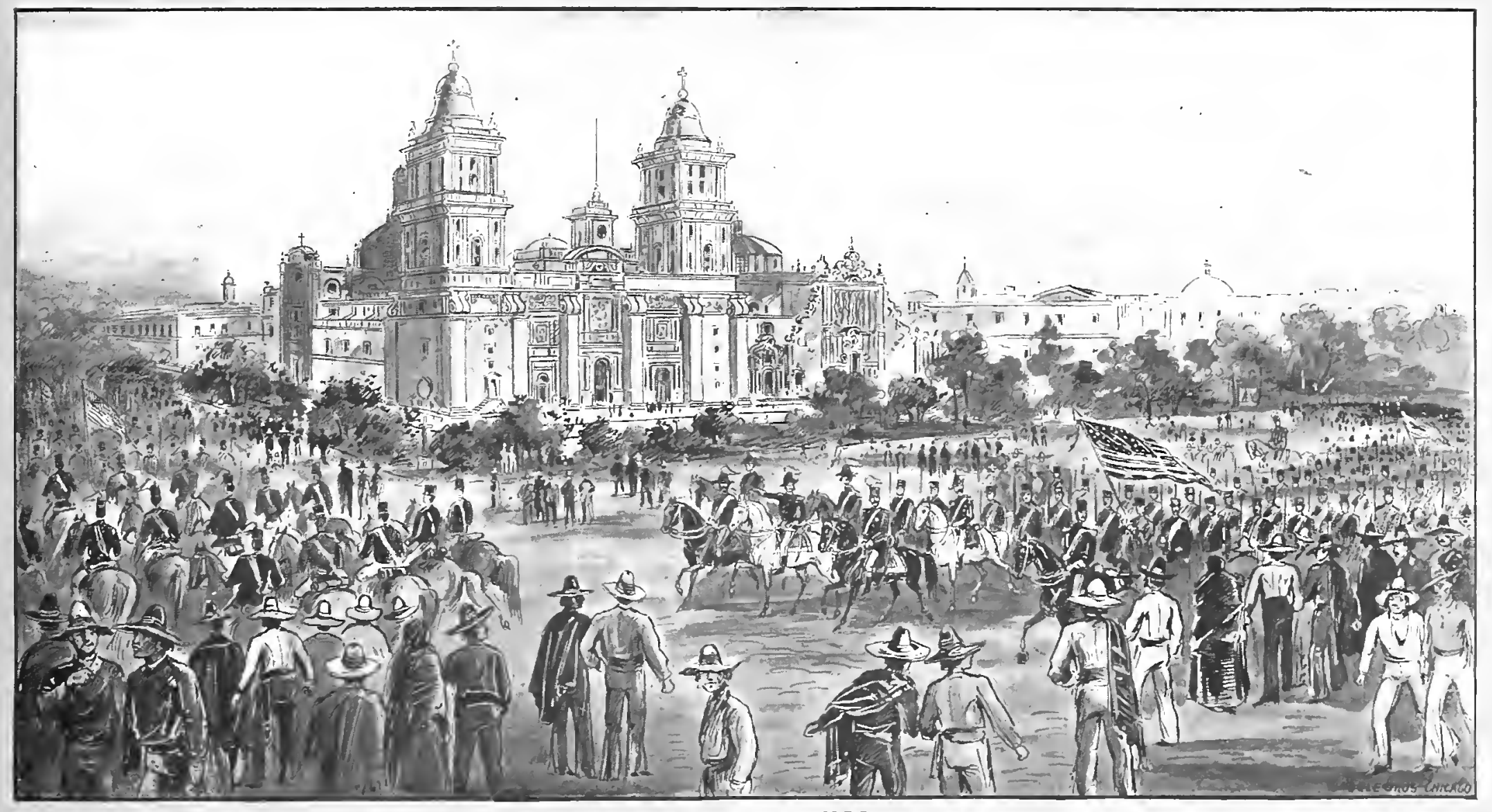


THE WOMAN'S BUILDING.

I no previous Exposition has the work of woman had given to it such complete recognition as in the World's Columbian Exposition. A national body of women, placed in charge of the interests of womcn, has carried to splendid results the movement to show how true it is that this is woman's century. The beautiful building, in which will be shown certain portions of the work of the women of the world, was designed by an architect who is a woman, and its decoration, assignment and management from the first has been entirely under the control of that sex. A prize was offered for the best design submitted by any woman architect for the building, and Miss Sophia G. Hayden of Boston was awarded the palm. The principal façade has an extreme length of too feet, the depth of the building being half this distance. Italian renaissance is the style selected. The first story is raised about ten feet from the ground line, and a wide staircase leads to the center pavilion. This pavilion, forming the main triple-arched entrance, with an open colonnade in the second story, is finished with a low pediment, enriched with a highly elaborate bas-relief. The corner pavilions have each an open colonnade added above the main cornice. Here are located the "hanging gardens." A wide lobby leads into the open rotunda, which reaches through the height of the building, and is protected by a richly ornamented skylight. This rotunda is surrounded by a two-story open arcade, as delicate and chaste in design as the exterior, the whole having a thoroughly Italian court-yard effect, admitting abundance of light to all rooms facing this interior space. On the first floor are located, on the left hand, a model hospital; on the right, a model kindergarten. The whole floor of the south pavilion is devoted to the retrospective exhibit, the one on the north to reform work and charity organization. Each of these foors is $80 \times 200$ feet. The curtain opposite the main front contains the library, bureau of information, records, etc. In the second story are located ladies' parlors, committee rooms, and dressing rooms, all leading to the open balcony in front. The whole second floor of the north pavilion incloses the great assembly-room and club room. The first of these is provided with an elevated stage for speakers. The south pavilion contains the model kitchen, refreshment rooms, reception rooms, and other homelike arrangements. The women of the country are justly proud of the structure which is devoted to their uses, and it is a most popular rendezvous for them at all times. 

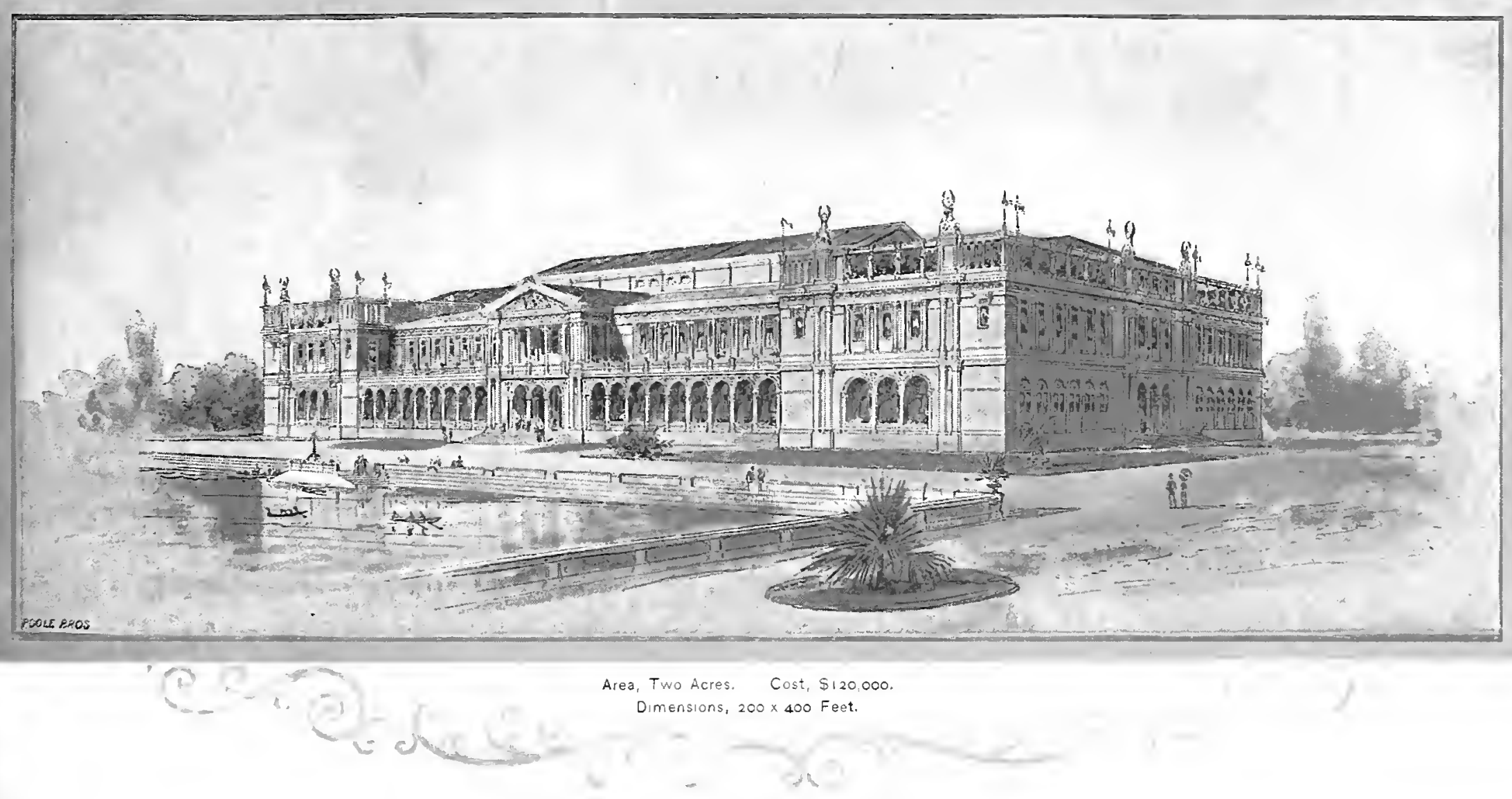


\section{EMANCIPATION.}

G REEDOM by inheritance we all prize as a treasure, and yet we know nothing of the pangs of bondage. How much greater the prize must seem to the thousands and millions who were once in bondage and are now free. They know in truth the measure of their fortune. The symbolical view on the opposite page is one to stir the hearts of millions. The contrasts in it are strongly marked. At the right stands a muscular specimen of the AfroAmerican race. Tatters cannot hide the manly grace of the pose. Far in the sky above and before him he has seen the word "F reedom" glowing before his eyes like the first rays of the sun after a night of terror. The sight seems to have been an inspiration to him. With a mighty effort he has taken a stride forward, has flung out his arms to grasp the promise, and at that instant the shackles from arms and legs, that have bound him from infancy, are shattered and cast aside. And so there he stands for the first time in his life a free man, with all that the word implies, shining from lis face and showing from his manner.

But the shackles were too strong and the scrf too crushed by the weight of years of oppression that he could by his own efforts release himself. A liberator was at hand when the hour came. Abraham Lincoln, enshrined in the heart of every negro, was the man of courage and wisdom and heart for the task. A man of the people, he rose from the ranks to the highest office in the gift of the world, the Presidency of the greatest Republic. He had been a laborer, a lawyer, and then a statesman; and, when a man was sought to take the helm of the Government in the most trying lour of the voyage of the ship of State, he was called to the task, and he never shirked it. Whatever his hand found to do he did with all his might. But he was wise, and he bided his time. Impatient ones urged that he should wait no time but hasten to release the slaves. Lincoln knew better-that he must delay until the effect would be strongest against the enemies of his country, and the enforcement of the order most practicable. Late in the fall of 1862 the President announced that if the war was still in progress on the first of January; he would then declare all the slaves free. The warning passed unheeded, and on the first of January, $I 863$, he issued a proclamation for the emancipation of some 3,000,000 slaves, and announced that black men would be enlisted in the army and navy. The final victories of the Union forces and the passage of the Constitutional amendment completed the work, and from that day there have been no slaves in the United States of America. 


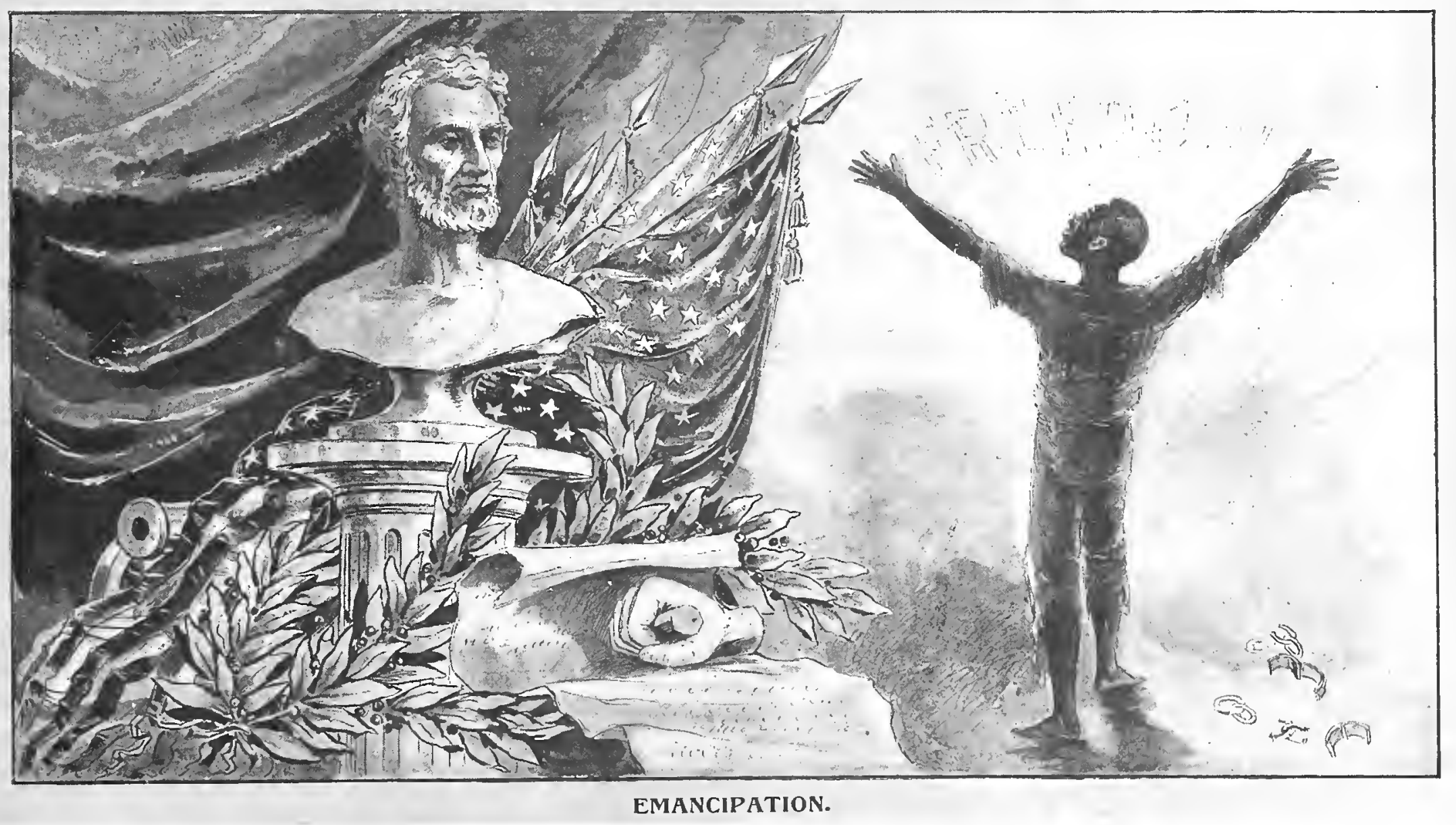


HORTICULTURE.

FVERY World's Farr has been the occasion of great display by florists and horticulturists of the treasures which they collect and rear. There havealso been numerous exhibitions in many countries where the display was exclusively of this character. But it is to be doubted if any predecessor has ever equaled the great World's Columbian Exposition in the horticultural department. The Horticultural Building, which is pictured on the opposite page, is a magnificent edifice of glass and iron, a veritable crystal palace, which rises with white walls out of the green sward of the surrounding lawns like a marble temple. This building is situated immediately south of the entrance to Jackson Park from Midway Plaisance, and faces east on the lagoon. In front is a flower terrace for outside exhibits, including tanks for nympheas and the Victoria Regia. The plan is a central pavilion with two end pavilions, each connected to the center pavilion with a front and rear curtain, forming two interior courts, each $88 \times 270$ feet. The center pavilion is roofed by a crystal dome, 187 feet in diameter and $1 \mathrm{~s} 3$ feet high, under which are exhibited the tallest palms, bamboos and tree ferns that could be procured. There is a gallery in each of the pavilions. The galleries of the end pavilions are used for cafes, the situation and the surroundings being particularly well adapted to recreation and refreshment. These cafes are surrounded by an arcade on three sides, from which charming views of the grounds may be obtained. In this building are varieties of flowers, plants, seeds, vines, horticultural implements, etc. Those exhibits requiring sunshine and light are shown in the rear curtains, where the roof is entirely of glass, and not too far removed from the plants. The front curtains and under the galleries are designed for the exhibits that require only an ordinary amount of light. Provision is made to heat such parts as require it. One of the beautiful effects produced in this building comes from the miniature mountain, 70 feet high in the center, upon which giant tree-ferns, palms and other vegetation grow. A mountain stream flashes down from one declivity to another, and plays hide-andseek among the foliage. Beneath this mountain is a cave, 80 feet in diameter and 60 feet high, brilliantly lighted by electricity, where, during the Fair, test is being made whether plants will grow as well under electric light as under sunlight. On the roof of the building, around the central dome, an elaborate display of roof-gardening is made. This whole palace of green is a bower of beauty. 


\section{HORTICULTURE.}

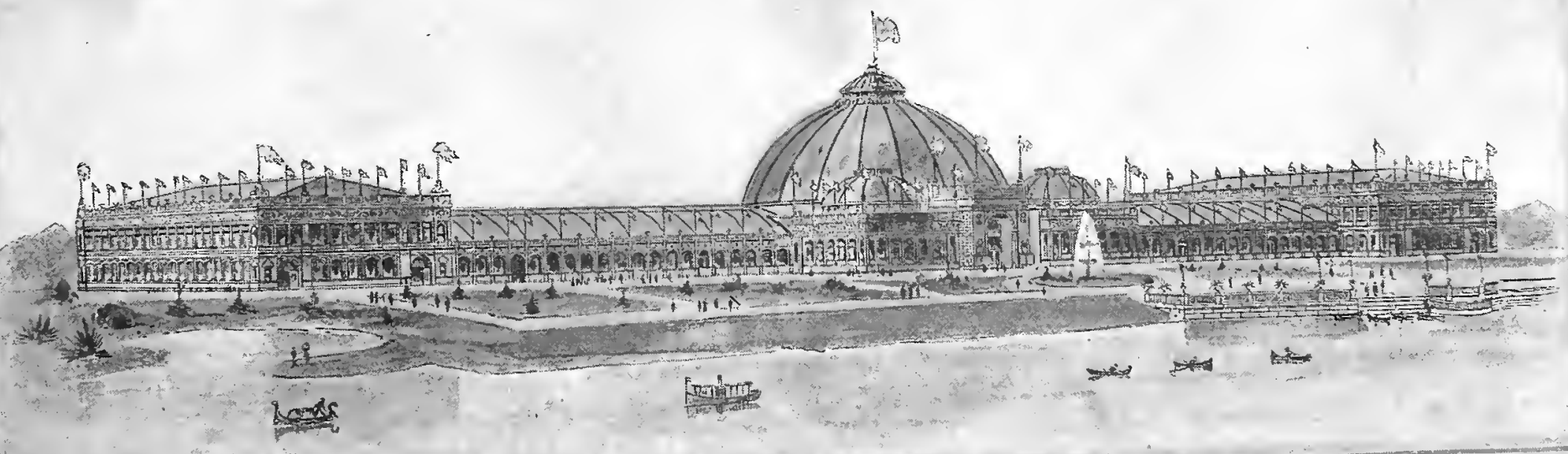

FDOLE BROS

Area, Six Acres. Cost, $\$ 300,000$

Dimensions, $250 \times 1000$ Feet.

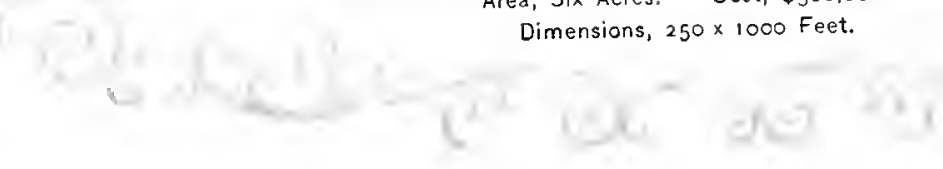


FAST And IVEST were linked at last by the completion of the Pacific Railway, one of the greatest engineering achievements of history, as well as one of the greatest of events measured by its influence upon the development and settlement of our country. The difficulty of communication between the Pacific coast and the States further east, during the war of the Rebellion had evidenced to the people of the United States, the strong necessity for some means of rapid transit. For many years surveys had been in progress, and at last construction was begun. The road was built from the IV est and from the East at the same time, and from both ends it was pushed to completion as rapidly as possible, towards the point of junction in the middle. The western terminus of the road was to be at San Francisco, and the eastern at Omaha, to which point there were already railroads built from the east. 'The road in the course of its progress from the Pacific coast eastward crosses nine mountain ranges. It was completed on May Io, I869, at Promontory Point, Utah. The last tie of laurel wood, with a plate of silver upon it, was laid, and the last spike, composed of iron, silver and gold, was driven in the presence of many onlookers. The telegraph wires were attached to the last rail, and the blows telegrapined to many parts of the continent the completion of the road. The total length of the road is two thousand miles, and its cost was one hundred and twelve million, two hundred and fifty-nine thousand, three hundred and sixty dollars. From Omaha to Ogclen, Utah, it is called the Union Pacific, and from that place to Oakland, which is opposite San Francisco on the bay, it is called the Central Pacific. The ceremonies attending the completion of the road were elaborate. Civilization met savagery, for there were present many Indians who marvelled at the works of their white brothers. Religious services were held, and the occasion will forever be considered a memorable one. Railroad growth has been enormous in this country since that time, and there are now about 175,000 miles of road in operation. The increase in some years has been more than II,000 miles. The Wabash has always taken high place among the roads of the country. Its territory is a rich one; it has macle special effort to cater to the comfort and convenience of its passengers, and it is unsurpassed in all that goes to make a first-class modern railway. It is a pioneer in the introduction of all improvements. Its service of through cars extends over a great portion of the country, and its connecting roads are always the most desirable. 


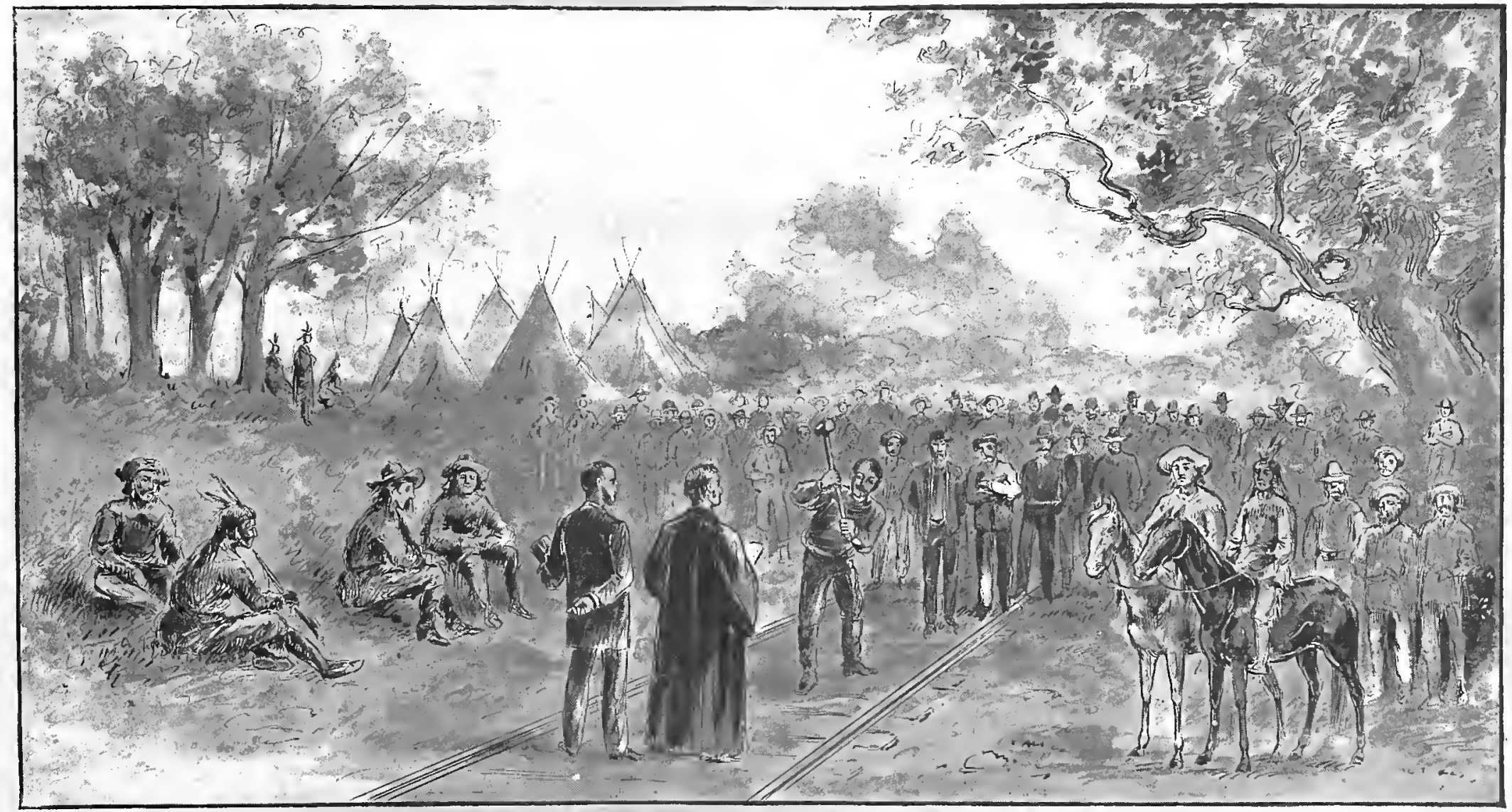

DRIVING THE LAST SPIKE ON THE UNION PACIFIC RAILROAD. 
NE of the most ornate of all the Exposition structures, and the second in order of expense, is the Palace of Mechanical Arts, or, as it is more generally termed, the MIachinery Hall. Like all the buildings on the grand plaza, it was designed with a view of making an effective background for displays of every kind, and in order to conform to the general richness on the court, and add to the festal appearance, the two façades on the court are enriched with colonnades and other architectural features. The design follows classical models throughout, the detail being borrowed from the renaissance of Seville and other Spanish towns, as being appropriate to a Columbian celebration. The main Machinery building is spanned by three arched trusses, and the interior presents the appearance of three railway train houses side by side, surrounded by a fifty-foot gallery. In each of these three long naves there is an elevated traveling crane rumring from end to end of the building. This was useful in moving machinery during construction, and when the Exposition opened, platforms were placed on them, from which a bird's-eye view of the whole building can be obtained. Shafting for power is carried on the same posts which support this traveling bridge. An arcade on the first story permits passage around the building under cover. A colonnade with a cafe at either end forms the connection between the Machinery and Agricultural Halls, and in the center of this colonnade is an archway through which one goes to the cattle exhibits. From this portico there is a view of nearly a mile down the lagoon, ending at the Fine Arts building, while the southern extremity of the vista is the obelisk and fountain between the two buildings, Agriculture and Machinery. The annex to the Machinery building is very large, but very simple. While in its parent structure the model was a railway train house, in the annex the type is that of a mill or foundry. It is built of wood in the most simple manner Electrical power is used in the annex, and steam power in the main Machinery hall. Attached to this great annex is the power-house, convenient to the tracks for coal supply, etc., containing the immense display of boilers, while in the adjoining portion of the annex building is established the enormous plant of engines and dynamos. This is the largest and most interesting display of electrical power ever made. The exhibits in this great Machinery hall and its annex are practically inexhaustible in interest, and the hum and whirr and clatter of industry is endless. 
MACHINERI'.

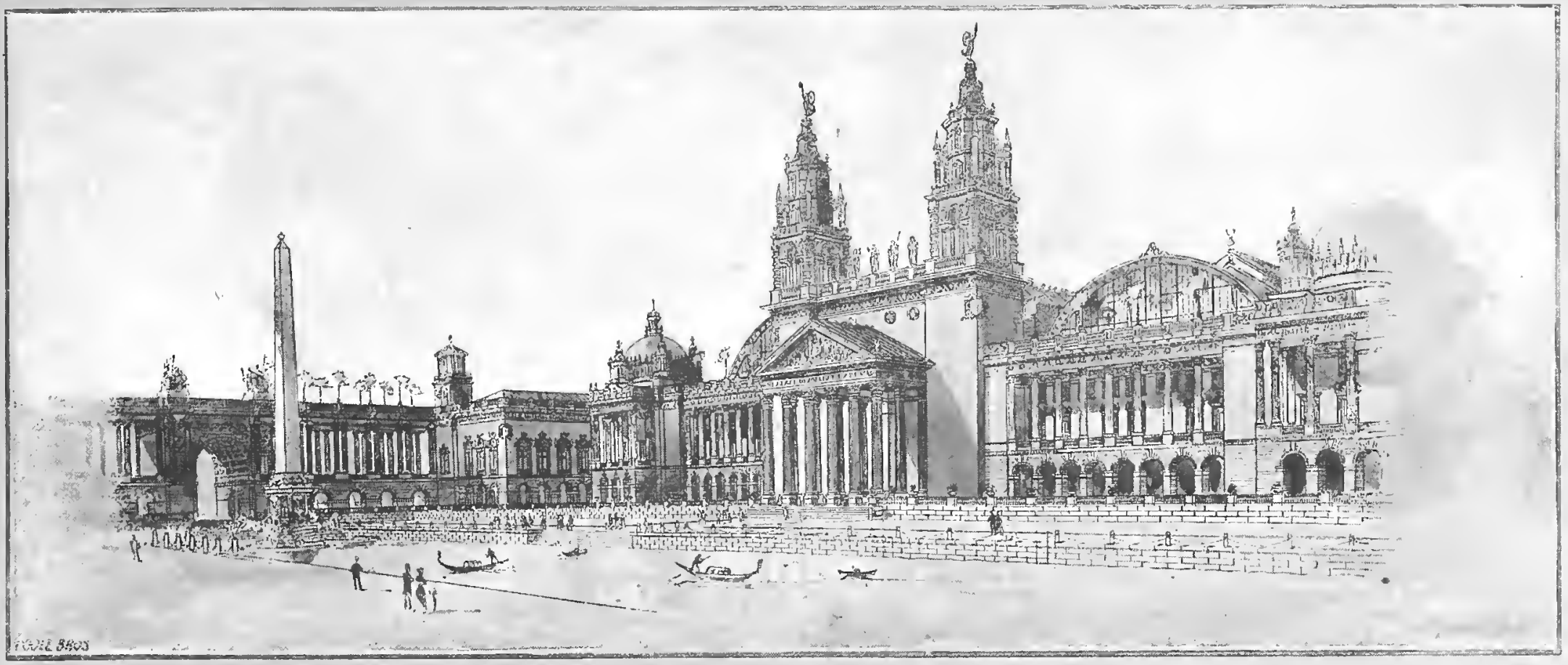

Total Area, Seventeen Acres, Cost, $\$ 1,200,000$.

Dimensions, $500 \times 850$ Feet. Annex, $490 \times 550$ Feet. 


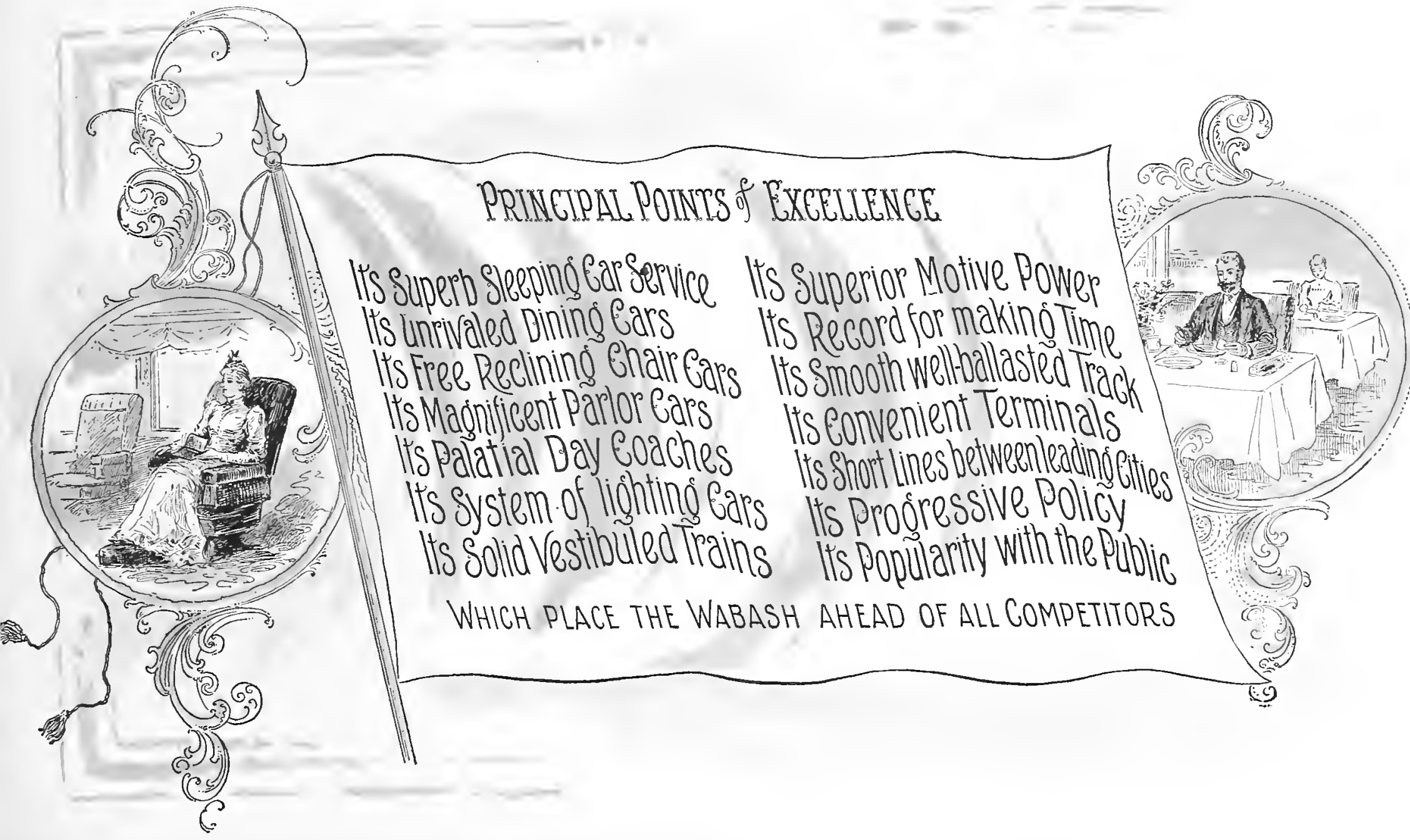






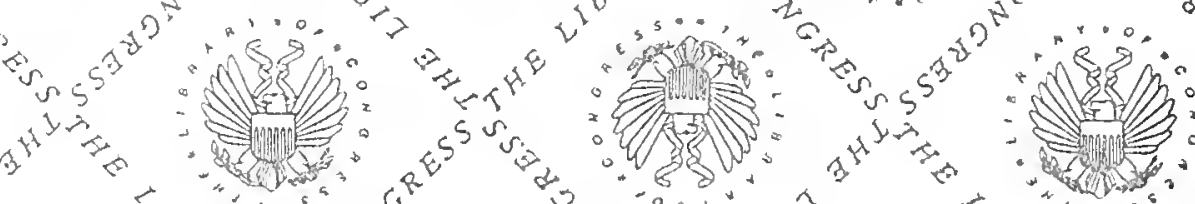
C O त a

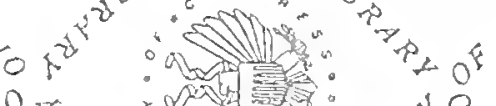

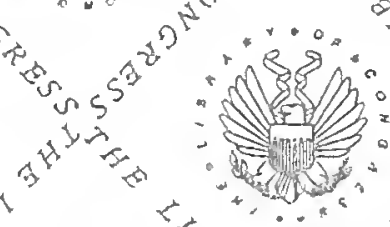

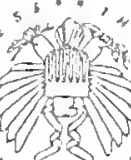

\section{"Nons:"}

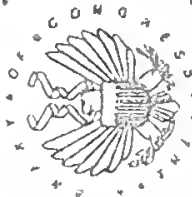

\section{$\mathrm{C}^{\mathrm{N}}$ \\ :}

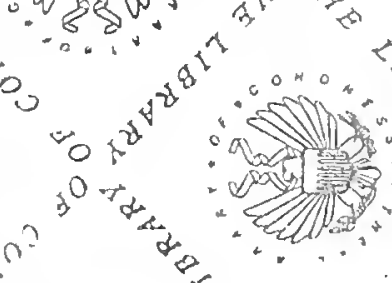

\section{0}

$14 x^{2}, 0^{2}$ 
LIBRARY OF CONGRESS

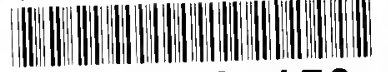

00199291531 